\title{
Determinants of bank interest margins: Impact of maturity transformation
}

\author{
Oliver Entrop ${ }^{\mathrm{a}, *}$, Christoph Memmel $^{\mathrm{b}}$, Benedikt Ruprecht ${ }^{\mathrm{b}}$, Marco Wilkens $^{\mathrm{c}}$

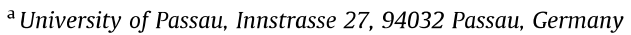 \\ ${ }^{\mathrm{b}}$ Deutsche Bundesbank, Wilhelm-Epstein-Strasse 14, 60431 Frankfurt, Germany \\ ${ }^{\mathrm{C}}$ University of Augsburg, Universitätsstrasse 16, 86169 Augsburg, Germany
}

\section{JEL classification \\ D21 \\ D22 \\ G21}

\section{Keywords:}

Term transformation

Interest rate risk

Optimal loan and deposit intermediation

fees

\begin{abstract}
A B S T R A C T
This paper explores the extent to which interest risk exposure is priced into bank margins. Our contribution to the literature is twofold: First, we extend the Ho and Saunders (1981) model to capture interest rate risk and expected returns from maturity transformation. Banks price interest risk according to their individual exposure separately in loan and deposit intermediation fees, but reduce (increase) these charges for loans (deposits) when positive excess holding period returns from long-term exposures are expected. Second, we test the model-derived hypotheses not only for the commonly investigated net interest margin but also for interest income and expense margins separately in a sample encompassing the German universal banking sector between 2000 and 2009. Our results suggest that banks price their individual interest rate risk and corresponding expected excess holding period returns via the asset side into the net interest margin. For liabilities, we find that interest rate risk exposure is only priced in by smaller, local banks.
\end{abstract}

\section{Introduction}

The theory of financial intermediation attributes a number of activities, commonly referred to as qualitative asset transformation, as core functions to banks (e.g. Bhattacharya and Thakor, 1993). These activities encompass credit risk, liquidity and maturity transformation. ${ }^{1}$ Maturity transformation evolves in most cases as a consequence of the provision of liquidity when fixed-rate longterm loans are financed using short-term deposits. The resulting maturity gap can be attractive for banks when term premia are present in the yield curve. Banks have incentives to increase their maturity gaps in order to boost profitability through increased interest income, which is known as the "lure of interest rate risk" (Greenbaum and Thakor, 2004, p. 138). However, by doing so, banks increase their interest rate risk (IRR) exposure and become vulnera-

\footnotetext{
* Corresponding author. Tel.: +49 851509 2460; fax: +49 8515092462.

E-mail addresses: oliver.entrop@uni-passau.de (O. Entrop), christoph.memmel@ bundesbank.de (C. Memmel), benedikt.ruprecht@bundesbank.de (B. Ruprecht), marco.wilkens@wiwi.uni-augsburg.de (M. Wilkens).

${ }^{1}$ We will use the notion of maturity and term transformation interchangeably. Although maturity is not the appropriate risk measure, maturity transformation evolved as a synonym for what can be referred to more generally as term transformation. Bhattacharya and Thakor (1993) address this issue.
}

ble to a reversal of the yield curve. This exposure can be distinguished with regard to its effects in two ways (Hellwig, 1994): First, reinvestment opportunity risk, i.e. the risk of having to roll over maturing contracts at a possibly disadvantageous rate. Second, valuation risk, i.e. the risk that changes in the yield curve reduce the net present value of a bank's loan and deposit portfolio.

Recent financial intermediation theory suggests that banks operate with excessive maturity mismatches (e.g. Segura and Suarez, 2012; Brunnermeier and Oehmke, 2013). Although these models focus on financial intermediaries' vulnerability to liquidity shocks such as the current financial crisis, they additionally verify intermediaries' exposure to increasing interest rates in "normal" times due to the interlinked roots of liquidity and maturity transformation. ${ }^{2}$ Recently, discussions about the existence of the bank risk-taking channel (Borio and Zhu, 2012), i.e. that low levels of nominal policy rates encourage financial intermediaries to take higher risks (and increase leverage), have gained attention. Therefore, discussions of new macroprudential regulatory frameworks include linking monetary policy and banking regulation in such a way that central banks should be prompted to consider higher policy

\footnotetext{
${ }^{2}$ For a brief theoretical comparison of interest rate and liquidity risk management see Brunnermeier and Yogo (2009).
} 
rates once the current turmoil is over (e.g. Blanchard et al., 2010). Rising interest rates in response to such a change in central bank policy would directly result in the aforementioned consequences of IRR.

Seminal models such as Ho and Saunders (1981) and Froot and Stein (1998) imply that banks should charge intermediation fees for the risks they keep on-balance. This paper examines the nexus between banks' involvement in maturity transformation, their profitability, and the intermediation fees they charge as risk compensation. First, we present a theoretical model which facilitates an analysis of the determinants influencing fees when banks engage in maturity transformation. Second, we test the modelderived hypotheses empirically by examining bank margins.

For our analysis, we extend the dealership model initially developed by Ho and Saunders (1981) to determine the factors that influence intermediation fees when a bank's balance sheet shows maturity mismatch. In the original Ho and Saunders model, a bank is viewed as a pure intermediary between lenders and borrowers of funds that sets prices in order to hedge against asymmetric inflows and outflows of funds. Assuming loans and deposits have an identical maturity, IRR only arises when loan volume does not match deposit volume and the existing volume gap is closed using short-term money market funds. Rolling over maturing short-term positions creates reinvestment (refinancing) opportunity risk. Maximizing expected utility, the bank charges fees that increase with the volatility of interest rates as a means of compensation for the potential losses. ${ }^{3}$

We relax the assumption of identical loan and deposit maturity. In our model, loans and deposits cannot, then, perfectly offset IRR, and exposure is not determined solely by interest rate volatility, but additionally by the bank-individual exposure captured in the bank's maturity structure, i.e. its maturity gap. As a consequence, banks increase (decrease) loan (deposit) fees with the size of the maturity mismatch. The economic rationale is that banks with higher interest risk exposure from holding long-term loans in their portfolios charge higher loan fees as risk compensation and bid more aggressively on deposits by lowering deposit fees rather than having to raise funding in the very short-term money market.

However, when positive valuation gains-so-called positive "holding period returns" above the money market rate-from long-term exposures are expected, banks partly reverse their pricing behavior by lowering (increasing) loan (deposit) fees. The rationale is that banks are already partly compensated for taking the risk from long-term loans by these returns (in expectation), which allows them to charge lower fees. For deposits, which are also characterized by longer maturities than the money market account, the opposite holds as this represents a liability position. The sum of the loan and deposit fees is the net fee income which increases with interest rate volatility and maturity mismatch and decreases with positive expected excess holding period returns from maturity transformation, given that banks have a positive maturity gap.

For the empirical analysis of the impact of maturity transformation on bank fees and their determinants, we utilize a comprehensive dataset of the entire German universal banking sector

\footnotetext{
${ }^{3}$ A series of authors extend the model: McShane and Sharpe (1985) shift interest uncertainty from loan and deposit returns to money market rates. Switching the source of risk involved a change from price to rate notation, which succeeding authors adopted. Allen (1988) considers two different types of loans with interdependent demand functions. Carbó and Rodríguez (2007) regard this second asset as a nontraditional activity and investigate how specialization and cross-selling behavior between assets influence several bank spreads instead of focusing solely on interest margins. Angbazo (1997) additionally attaches credit risk to the interest rate risk associated with the bank's loans and derives a risk component that depends not only on the volatility of risk sources, but also on the co-movement thereof. The operating cost needed to provide intermediation services is taken into account by Maudos and Fernández de Guevara (2004). Finally, Maudos and Solís (2009) combine the independently derived two-asset-type models and all other extensions into a single integrated model.
}

between 2000 and 2009. The German banking system is well-suited for this analysis. First, as Germany is a bank-based financial system (e.g. Schmidt et al., 1999), the bulk of liquidity is provided via maturity transformation by financial intermediaries. The predominance of (long-term) fixed-rate loans intended to be held until maturity instead of being securitized, and the strong reliance on (demand and especially savings) deposits are specific characteristics of the German banking sector. Therefore, German banks appear to be vulnerable to IRR from maturity transformation (Memmel, 2011). Second, IRR management is conducted more frequently on-balance compared to market-based financial systems which are more reliant on derivatives hedging. ${ }^{4}$ Risk management is implemented through buffer stocks of liquid assets and the intertemporal smoothing of non-diversifiable risks (Allen and Santomero, 2001), such as liquidity and interest risk, as well as interbank lending in bank networks. The latter shield (smaller) banks in major banking groups against monetary contractions and prevent them from having to reduce lending as a consequence of large deposit outflows and drastic balance sheet duration adjustments (Ehrmann and Worms, 2004).

In our empirical analysis, we not only test the impact of the optimal loan and deposit fee determinants on the commonly investigated net interest margin (NIM), but are also the first to test the hypotheses for the asset and liability side, i.e. interest income and expense margins (IIM and IEM), separately. As model-derived optimal intermediation fees economically represent the difference between bank-set interest rates and fair market rates of the same maturity, we use detailed supervisory data on bank assets' and liabilities' maturities to create bond portfolios that mimic the maturity structure of the bank. The coupon payments from these portfolios control for the impact of market rates on the respective margins in our analysis, which allows us to separate the impact of the theoretical determinants on the fee portion of the margins.

We find the empirical results for the NIM to be consistent with our model hypotheses, i.e. net intermediation fees increase with the maturity gap and decrease with expected returns from maturity transformation; however, the effects of the expected return from maturity transformation are minor. All margins positively depend on interest rate volatility, which contradicts the modelderived hypothesis for the IEM. Disentangling the NIM into IIM and IEM, we find strong evidence that banks price their maturity gap and corresponding expected returns on the asset side, whereas the model-implied effects for the liability side can only be found for cooperative banks. Our results, therefore, imply that the effects found for the NIM are mainly driven by the asset side.

The remainder of the paper is organized as follows. In Section 2 we derive the theoretical model with differing loan and deposit maturities. An overview of the data and the institutional characteristics of the German commercial banking sector is provided in Section 3, where the variables used to proxy for the derived determinants are also introduced. Section 4 presents the econometric model (Section 4.1) and the empirical results. Institutional differences in the banking sector are taken into account by investigating three different sub-samples, for savings, cooperative and other, mainly private commercial, banks. First, we examine the commonly investigated net interest margin (Section 4.2), and then, separately, the interest income and expense margin (Section 4.3). Section 4.4 investigates the extent to which the previously derived

\footnotetext{
4 Allen and Santomero (2001) explain this difference between market-based systems, such as the U.S., and bank-based systems, such as Germany, drawing on the model of Allen and Gale (1997). The lack of competition from financial markets is considered to be the basis for German financial intermediaries' ability to manage risk on-balance. Purnanandam (2007) finds that small U.S. commercial banks likewise manage IRR less frequently via derivatives, but instead on-balance by adjusting their maturity gap in line with interest rate changes.
} 
results are robust to the financial crisis. Section 5 presents our concluding remarks.

\section{Theoretical model}

In this section, we present an augmented dealership model of Ho and Saunders (1981) that explicitly includes maturity transformation on account of loan maturity exceeding deposit maturity. To incorporate the resulting valuation risk, loans and deposits are modeled as fixed-rate contracts with different maturities, and thus with different sensitivities to changes in the yield curve. To ensure that the bank's risk management decision that we are most interested in is kept as simple as possible, we adopt the price notation of Ho and Saunders (1981) and Allen (1988) and focus on the provision of a single loan and a single deposit. ${ }^{5}$

The bank sets prices at which it is willing to grant loans $\left(P_{L}\right)$ and take in deposits $\left(P_{D}\right)$ at the beginning of the decision period before the demand for loans and the supply of deposits can be observed, and does not adjust them afterwards. Fees are set as mark-ups $a$ on deposits and mark-downs $b$ on loans, in relation to what the bank considers to be the "fair" price, $p_{D}$ and $p_{L}$, of the given transaction:

$P_{D}=p_{D}+a, \quad P_{L}=p_{L}-b$.

The fair price can be best thought of as the price of a coupon-paying bond with identical risk characteristics as the underlying transaction. Assuming that only loans bear credit risk, their fair price $p_{L}$ is that of a (corporate) bond with an identical probability of default and recovery rate, whereas the fair price of a deposit $p_{D}$ corresponds to a default-free (government) bond of identical maturity.

We assume that the bank charges (demands) rates equaling par yields, i.e. fair market rates, of the underlying bond, which implies that the fair price of a new transaction is at par when it is initiated. Consequently, the cost (and profits) of financial intermediation are solely accounted for by the magnitude of the up-front fees $a$ and $b$. Mark-ups $a$ on deposits and mark-downs $b$ on loans result in an effective yield to maturity below that of bond funding for deposits, and above that of bond investing for loans. ${ }^{6}$

The bank's initial wealth portfolio $W_{0}$ at the beginning of the period consists of three different portfolios: (i) long positions in loans $L$, (ii) short positions in deposits $D$, and (iii) money market funds $M$, which can take either long or short positions, all denoted at market values:

$W_{0}=L_{0}-D_{0}+M_{0}$.

The length of the planning horizon $T$ is shorter than the maturities of the loans and deposits. Thus, the values of the loan and deposit portfolios in $T$ are random due to unexpected changes in the yield curve or in default risk, i.e. the returns until $T$ of both the loan and the deposit portfolio are subject to IRR, with the loan return also being exposed to credit risk. Returns are the returns of the underlying bonds, since intermediation fees are not considered as they are charged in advance. Loans generate an expected rate of return of $r_{L}$, and deposits of $r_{D}$ until $T$. The uncertainty of returns

\footnotetext{
${ }^{5}$ In the Internet Appendix we present a general multi-output model that additionally incorporates non-traditional banking (NTB) activities as a second asset class in line with Allen (1988), Carbó and Rodríguez (2007) and Maudos and Solís (2009). This model is applicable to countries where NTB is more relevant than it is Germany, where NTB is still of limited, albeit increasing importance for the majority of banks (e.g. Busch and Kick, 2009). The Internet Appendix also derives the general model in more detail than this section, where we focus on the key steps and economic intuition of the model set-up and of the results.

${ }^{6}$ To illustrate bank pricing decisions, we give an example. Let us assume the bank offers a two-year deposit and the par yield of a two-year bond equals $3 \%$. The bank will pay this fair interest rate to its depositors. However, the bank charges up-front intermediation fees $a$ of, let us say, $1.5 \%$, i.e. the depositor has to deposit $\$ 101.5$ for a claim guaranteeing the repayment of $\$ 100$. By doing this, the bank decreases the effective yield to maturity paid on deposits below the fair market rate of $3 \%$.
}

will be captured in stochastic terms $\widetilde{Z}$. Interest rate risk in loans will be displayed as $\widetilde{Z}_{I}$, credit risk as $\widetilde{Z}_{C}$, and interest rate risk in deposits as $\widetilde{Z}_{D}$. All stochastic terms have an expected mean of zero and are trivariate normally distributed $N_{3}(\mathbf{0}, \Sigma)$, with variance-covariance matrix $\Sigma$. If loan maturity is assumed to exceed deposit maturity, normally-shaped yield curves lead, in general, to higher (expected) returns on long-term bonds compared with short-term bonds, i.e. $r_{L}$ $>r_{D}$. In this case, loan values are more sensitive to changes in the yield curve and their return volatility is higher than that of deposits, i.e. $\sigma_{I}^{2}>\sigma_{D}^{2}$. The rate of return on the money market account, by contrast, is certain over the period and denoted $r$.

Managing loan and deposit portfolios generates operating $\operatorname{cost} C$ each period, which is monotonically increasing functions of the market values of the loan and deposit portfolios. The bank's endof-period wealth is given by:

$$
\begin{aligned}
W_{T}= & \left(1+r_{L}+\widetilde{Z}_{I}+\widetilde{Z}_{C}\right) L_{0}-\left(1+r_{D}+\widetilde{Z}_{D}\right) D_{0}+(1+r) M_{0} \\
& -C\left(L_{0}\right)-C\left(D_{0}\right) .
\end{aligned}
$$

The bank maximizes expected utility. The utility function $U(W)$ is twice continuously differentiable, with $U^{\prime}>0$ and $U^{\prime \prime}<0$ in order to reflect risk aversion. In line with the previous literature, the expected end-of-period utility, $E U(W)$, is approximated using a second-order Taylor series expansion around the expected level of $E(W)=\bar{W}$ and given by:

$E U(W)=U(\bar{W})+\frac{1}{2} U^{\prime \prime}(\bar{W})\left[\left(\sigma_{I}^{2}+2 \sigma_{I C}+\sigma_{C}^{2}\right) L_{0}^{2}-2\left(\sigma_{I D}+\sigma_{C D}\right) L_{0} D_{0}+\sigma_{D}^{2} D_{0}^{2}\right]$

where $\sigma_{I C}$ denotes the covariance between the interest rate and credit risk of the loan portfolio and $\sigma_{I D}\left(\sigma_{C D}\right)$ the covariance between the interest rate risk (credit risk) of the loan and the interest rate risk of the deposit portfolio.

When a new deposit $Q_{D}$ arrives, the overall volume of deposits increases to $D_{0}+Q_{D}$. As attracting deposits equals selling bonds at a mark-up of $a$, the money market account increases to $M_{0}+Q_{D}(1+a)$. Assuming-analogously to the previous literature-that second-order terms of intermediation fees, expected returns and operating cost are negligible, the increase in expected utility due to a new deposit inflow is ${ }^{7}$ :

$$
\begin{aligned}
\Delta E U\left(W \mid Q_{D}\right)= & U^{\prime}(\bar{W})\left[\left[(1+r)(1+a)-\left(1+r_{D}\right)\right] Q_{D}-C\left(Q_{D}\right)\right] \\
& +\frac{1}{2} U^{\prime \prime}(\bar{W})\left[\sigma_{D}^{2}\left(2 D_{0}+Q_{D}\right) Q_{D}-\left(\sigma_{I D}+\sigma_{C D}\right) Q_{D} L_{0}\right]
\end{aligned}
$$

where $C\left(Q_{D}\right)$ denotes the additional operating cost associated with the new transaction.

Similarly, new loan demand $Q_{L}$ results in an increase in the loans' market values to $L_{0}+Q_{L}$ and a decrease of the money market account to $M_{0}-Q_{L}(1-b)$. The resulting increase in expected utility under the same assumptions as before is:

$$
\begin{aligned}
\Delta E U\left(W \mid Q_{L}\right)= & U^{\prime}(\bar{W})\left(\left[\left(1+r_{L}\right)-(1-b)(1+r)\right] Q_{L}-C\left(Q_{L}\right)\right) \\
& +\frac{1}{2} U^{\prime \prime}(\bar{W})\left[\left(\sigma_{I}^{2}+2 \sigma_{I C}+\sigma_{C}^{2}\right)\left(2 L_{0}+Q_{L}\right) Q_{L}\right. \\
& \left.-2\left(\sigma_{I D}+\sigma_{C D}\right) Q_{L} D_{0}\right] .
\end{aligned}
$$

The bank sets loan fees $a$ and deposit fees $b$ to cover unexpected losses from interest rate and credit risk. However, increasing the

\footnotetext{
${ }^{7}$ Ho and Saunders (1981) and all succeeding models calculate the increase in net wealth to be $a Q_{D}$. However, we choose the intermediation fees to be earned in advance and allow them to earn the risk-free rate (see Freixas and Rochet, 2008, p. 232). The same approach is used for newly demanded loans.
} 
magnitude of fees demanded will limit the incentives of deposit supply as well as loan demand. Transaction volumes $Q_{D}$ and $Q_{L}$ are exogenously determined, but the likelihood of a new transaction occurring will decrease with the magnitude of fees and follows independent Poisson processes with intensity $\lambda$ :

$\lambda_{D}=\alpha_{D}-\beta_{D} \times a$,

$\lambda_{L}=\alpha_{L}-\beta_{L} \times b$

The bank's objective function, conditional to, at most, a single transaction occurring, is to set optimal intermediation fees so as to maximize its expected end-of-period utility, i.e. the problem of maximization is as follows:

$$
\begin{aligned}
\max _{a, b} E U(\Delta W)= & \left(\alpha_{D}-\beta_{D} \times a\right) \Delta E U\left(W \mid Q_{D}\right) \\
& +\left(\alpha_{L}-\beta_{L} \times b\right) \Delta E U\left(W \mid Q_{L}\right) .
\end{aligned}
$$

Rearranging first-order conditions, the optimal loan fee is

$$
\begin{aligned}
b^{*}= & \frac{1}{2} \frac{\alpha_{L}}{\beta_{L}}+\frac{1}{2} \frac{C\left(Q_{L}\right)}{Q_{L}(1+r)}-\frac{1}{2} \frac{r_{L}-r}{(1+r)}-\frac{1}{4} \frac{U^{\prime \prime}(\bar{W})}{U^{\prime}(\bar{W})} \\
& \times \frac{\left[\left(\sigma_{I}^{2}+2 \sigma_{I C}+\sigma_{C}^{2}\right)\left(2 L_{0}+Q_{L}\right)-2\left(\sigma_{I D}+\sigma_{C D}\right) D_{0}\right]}{(1+r)},
\end{aligned}
$$

and the optimal deposit fee

$$
\begin{aligned}
a^{*}= & \frac{1}{2} \frac{\alpha_{D}}{\beta_{D}}+\frac{1}{2} \frac{C\left(Q_{D}\right)}{Q_{D}(1+r)}+\frac{1}{2} \frac{r_{D}-r}{(1+r)}-\frac{1}{4} \frac{U^{\prime \prime}(\bar{W})}{U^{\prime}(\bar{W})} \\
& \times \frac{\left[\sigma_{D}^{2}\left(2 D_{0}+Q_{D}\right)-2\left(\sigma_{I D}+\sigma_{C D}\right) L_{0}\right]}{(1+r)} .
\end{aligned}
$$

The optimal fees on loans $a^{*}$ and deposits $b^{*}$ both depend on four components: (i) market power, (ii) an operating cost, (iii) an expected excess holding period return, and (iv) a risk component. Whereas previous models only observe the influence of three components, the influence of the expected excess holding period returns $\left(r_{L}-r\right)$ and $\left(r_{D}-r\right)$, respectively, is newly derived. This effect as well as the new special structure of the risk component originate from the bank's risk transformation, encompassing maturity transformation, as introduced in our model.

Market power. The competitive structure of the banking industry is determined by the extent to which (the likelihood of) loan demand and deposit supply are inelastic with respect to the intermediation fees charged, represented by the factor $\beta$. With an increasing ratio of $\alpha / \beta$, elasticity decreases and banks gain market power which translates into higher fees.

Operating cost. The average operating $\cos t C$ incurred per unit of transaction volume $Q$ i.e. $C\left(Q_{x}\right) / Q_{x}$, with $x=L, D$ for loans and deposits, respectively, is passed on to lenders and borrowers as in a standard monopolistic setting. For example, banks with higher personnel costs associated with the new transaction or having higher costs because they offer their customers more services such as a more closely knit branch network will charge higher fees in loans and deposits.

Expected excess holding period returns. In addition to cost banks also take expected excess holding period returns from risk transformation into account when setting loan and deposit fees, a new result derived from our model. With positive expected excess holding period returns over the horizon $T$, i.e. $\left(r_{L}-r>0\right)$ and $\left(r_{D}-r>0\right)$, respectively, loan fees are reduced and deposit fees increased. This means that banks are willing to lower loan fees during periods in which granting loans is expected to generate positive risk transformation income above the risk-free rate (in the form of coupon payments on the underlying bond and possible valuation gains). All other things being equal, higher expected excess returns compensate the bank more for risk-taking and allows it to lower the loan fees demanded from the customer to cover unexpected losses. For deposits, the opposite holds, resulting in increased intermediation fees, as they represent a liability position.

Qualitatively, we observe the same effect for expected excess returns as for operating cost when a monopolistic supplier (demander) determines the profit-maximizing price in the Monti-Klein model of financial intermediation: expected excess holding period returns in loans can be regarded as reductions in marginal cost, and the expected profits are passed on to customers in the same way as marginal costs are priced (Freixas and Rochet, 2008, pp. 57-59), and vice versa for deposits.

Risk component. The risk component consists of the product of the bank's absolute risk aversion $\left(-U^{\prime \prime} / U^{\prime}\right)$ and the bank's overall risk exposure from the perspective of the side of the balance sheet the transaction is related to. Given positive risk exposure, banks facing higher levels of risk aversion charge higher fees.

Eqs. (11) and (10) reveal that fees increase with the total risk exposure of the balance sheet side the initiated transaction belongs to and decrease with the hedging ability of the opposite balance sheet side. More specifically, loan fees increase with a loan's interest $\left(\sigma_{I}^{2}\right)$ and credit risk $\left(\sigma_{C}^{2}\right)$, as well as their covariance, and the volume of loans affected by such risks after the transaction occurs $\left(L_{0}+Q_{L}\right)$. However, fees are reduced when deposits hedge the loan's risk, i.e. by increasing covariance of the loan's risk and the interest risk inherent in deposits, $\left(\sigma_{I D}+\sigma_{C D}\right)$, weighted by the volume of deposits $D_{0}$. When deposits are being priced, the opposite holds.

Ignoring credit risk, i.e. $\sigma_{C}^{2}=\sigma_{I C}=\sigma_{C D}=0$, the risk exposure in loan fees behaves very much like a bank's (modified) duration gap. The modified duration gap measures the bank balance sheet's sensitivity to (small) changes in the yield curve by accounting for the volume-weighted net effect of interest rate changes on assets' and liabilities' present values. Ceteris paribus it increases with a longer (shorter) maturity of the loans (deposits). Qualitatively, the same holds for the risk components: We have $\sigma_{I D}=\sigma_{I}^{2}$ when loans and deposits have the same maturity; thus, the interest rate risk of deposits offsets that of loans in this case, with the exception of volume effects. When the loan maturity increases, we can expect higher $\sigma_{I}^{2}$ and a reduced hedging ability of the deposits, as the correlation between respective returns tends to decrease with a higher maturity difference. This implies that the risk component increases, yielding higher loan fees $b^{*}$.

For the risk component in deposit fees, analogous considerations hold; however, it is linked to a reverse duration gap as it measures the risk of the deposit portfolio less the hedging ability of the loan portfolio. This implies that the deposit fee $a^{*}$ decreases with an increasing duration gap. The economic rationale is that banks with high IRR from holding long-term loans in their portfolios would be willing to bid more aggressively on deposits by offering more favorable rates.

In sum, loan and deposit fees are determined by the same four components introduced above. Market power, operating cost and the risk component have a positive impact on fees charged. Positive expected excess holding period returns show a positive effect on loan fees and a negative effect on deposit fees, as a result of the opposed positions-long vs. short-of their underlying portfolios.

As previous literature focuses on the pure intermediation spread $s^{*}$, defined as the sum of both intermediation fees, i.e. $s^{*}=a^{*}+b^{*}$, its determinants are illustrated below: 
$s^{*}=\frac{1}{2}\left(\frac{\alpha_{L}}{\beta_{L}}+\frac{\alpha_{D}}{\beta_{D}}\right)+\frac{1}{2}\left(\frac{C\left(Q_{L}\right)}{Q_{L}(1+r)}+\frac{C\left(Q_{D}\right)}{Q_{D}(1+r)}\right)-\frac{1}{2} \frac{r_{L}-r_{D}}{(1+r)}-\frac{1}{4} \frac{U^{\prime \prime}(\bar{W})}{U^{\prime}(\bar{W})} \frac{\left[\left(\sigma_{I}^{2}+2 \sigma_{I C}+\sigma_{C}^{2}\right)\left(2 L_{0}+Q_{L}\right)-2\left(\sigma_{I D}+\sigma_{C D}\right)\left(D_{0}+L_{0}\right)+\sigma_{D}^{2}\left(2 D_{0}+Q_{D}\right)\right]}{(1+r)}$.

It should be noted that the pure spread solely encompasses fees related to transaction uncertainty (Ho and Saunders, 1981) but does not fully represent the net interest income (NIM)-defined as net interest income to total assets in the following analysis-in our model. Owing to the different maturities of loans and deposits, the interest payments from the underlying bonds usually do not offset each other but contribute to the NIM as well.

The same four components, found separately in loan and deposit fees, also influence the pure spread. Market power and operating cost are simply the sum of the terms found in loan and deposit fees, and can be interpreted as the bank's overall market power and operating cost from financial intermediation, respectively. The expected excess holding period returns determining loan and deposit fees (partly) offset each other and translate into $\left(r_{L}-r_{D}\right)$, the expected holding period return from overall risk transformation. $\left(r_{L}-r_{D}\right)$ can be expected to take positive values in times of normally-shaped yield curves due to, in general, a positive maturity transformation. Hence, the bank is willing to lower overall fees when it expects positive returns from maturity transformation. The combined risk component rises in both the loan's and the deposit's risks, always weighted by the new business volume after the transaction has taken place, $\left(L_{0}+Q_{L}\right)$ and $\left(D_{0}+Q_{D}\right)$, and is reduced by the covariance hedges times the volume of the total initial interest-bearing business, i.e. $\left(D_{0}+L_{0}\right)$.

\section{Data}

\subsection{The German banking system}

To empirically test the predictions derived from our theoretical model, we utilize a dataset covering the entire German commercial banking sector for a range of ten years between 2000 and $2009 .^{8}$ The time span contains substantial variations in the yield curve, with steep and flat term structures.

The German banking system comprises three pillars where affiliation to a certain pillar is determined by ownership (e.g. Brunner et al., 2004). The three pillars are private commercial banks, stateowned banks and banks of the cooperative sector. The majority of German banks belong to the last two pillars. State-owned savings banks and cooperative banks operate each in geographically delimited areas, and there is almost no competition between them across local banking markets. In an international context, they are small to medium-sized with only limited direct access to the capital market. The business models of these banks are very homogeneous and mainly consist of pure intermediation services, as assumed in the model. Income from maturity transformation contributes substantially to net interest income (Memmel, 2011) which in turn represents to the largest fraction of banks' earnings, whereas non-interest fee and especially trading income are of limited importance only.

As a general rule, savings and cooperative banks do not access the capital markets independently, but mainly through the head

\footnotetext{
${ }^{8}$ Data for 1999 are used to create instruments from first-differenced covariates.
}

institutions of their respective interbank networks. The head institutions provide liquidity to their affiliated members and allow them to manage their duration gaps through interbank lending. These interbank networks shield the smaller savings and cooperative banks against monetary contractions, and against having to reduce lending as a consequence of deposit outflows and drastic balance sheet duration adjustments (Ehrmann and Worms, 2004). The mitigated impact of the monetary transmission channel allows us to investigate interest margins that are only moderately affected by changes in the volume of interest-bearing business.

We investigate the full German universal banking sector, which gives us a broad sample of more than 2000 banks and 16,000 bank years. Such a sample size, though limited to a single country, exceeds most of the international studies on determinants of bank margins conducted so far (e.g. Demirgüç-Kunt and Huizinga, 1999; Saunders and Schumacher, 2000; Maudos and Fernández de Guevara, 2004; Claeys and Vander Vennet, 2008)-except for Carbó and Rodríguez (2007) and Nguyen (2012), who have larger-sized samples.

Although only limited data is publicly available, supervisory data lets us utilize detailed information on a bank's lender and borrower characteristics and maturities. The data used in this analysis are based on the following supervisory data collected by the Deutsche Bundesbank: balance sheet figures are taken from the yearend monthly balance sheet statistics, cost and revenues from banks' income statements, and additional bank-specific information stems from auditors' reports. Macroeconomic and term structure data are those provided to the public on the Deutsche Bundesbank's website. Earlier data cannot be used owing to a major change in the reporting structure of the monthly balance sheet statistics in 1998.

A further point that has to be taken into account is the treatment of mergers and the effect thereof on the comparability of pre- and post-merger accounting figures. During the sample period, the German banking sector experienced a major wave of consolidation, resulting in several hundred mergers, most notably among savings and cooperative banks. In order to account for structural changes in the time series of variables following mergers, a new synthetic bank is created after every merger. Thus, for a single merger between two different banks, three synthetic banks exist: two pre-merger banks and another post-merger one. ${ }^{9}$

To capture differences resulting from the institutional characteristics of the banking sector, we initially conduct our analysis on the complete sample, but subsequently divide the latter into three sub-samples. Although the three pillars would provide a good pre-specified segmentation, we place the head institutions

\footnotetext{
${ }^{9}$ Mergers inevitably lead to an increase in total assets, total interest-bearing assets and liabilities, and equity capital as two separate banks are simply added together. As the aforementioned variables are all used as explanatory variables (in logarithms) for estimating Lerner indices, the approach is especially necessary. The procedure is also adequate for ratios of accounting measures, such as the frequently investigated net interest income margin. Within the pillars of savings and cooperative banks, it is common for a healthier bank to be asked to take over a distressed bank in a neighboring region. In this case, the merged profitability measures of the bank taking over the other one are likely to deteriorate in the year after the merger.
} 
of the state-owned pillar (mainly Landesbanken) and the cooperative pillar into a group with all private commercial banks, this group being referred to hereinafter as "other banks". The rationale for reclassifying these institutions to a different group is the difference between head institutions and their affiliated savings and cooperative banks not just with regard to size, business model and capital market access, but also in terms of IRR management (Ehrmann and Worms, 2004).

\subsection{Variables}

The dependent variables we investigate are (i) the net interest margin (NIM), (ii) the interest income margin (IIM), and (iii) the interest expense margin (IEM). NIM is defined as interest income minus interest expenses to total assets. IIM sets interest income in relation to total interest-earning assets, which are composed of loans and securities held. IEM captures interest expenses to total interest-paying liabilities, which consist of interbank and non-bank funding, deposit accounts and securities issued. When we analyze one of these margins with an explanatory variable that has an identical numerator for all three margins, we put the explanatory variable in relation to the denominator of the interest margin examined. That is, we divide by total assets for the NIM, total interest-earning assets for the IIM, and total interest-paying liabilities for the IEM, respectively. Doing so, only the variability of the numerator can have an influence on the significance of the coefficients derived.

It should be noted that these dependent variables are not equivalent to the (optimal) loan and deposit fees from the theoretical model, but encompass them. The interest income and expenses from new loan and deposit transactions observed at the end of the period are the par yield coupon payment of a risky long-term corporate bond plus the loan fees, and the par yield coupon payment of a shorter-term default-free government bond less the deposit fee, respectively.

This generates two implications for our empirical design. First we need to control for coupon payments of fairly-priced capital market bonds as they are included in the dependent variables by construction. We will do this via what we call "revolving portfolios" of bonds, mimicking the maturity structure of the bank. Second, interest expenses and the deposit fees $a^{*}$ derived from the model are negatively linked. Hence, empirical proxies for deposit fee determinants should exhibit the opposite of the theoretically derived impact. ${ }^{10}$

The following sub-sections describe the variables proxying for the determinants derived from the model, additional bank-specific and macroeconomic control variables, and the construction of the revolving portfolios. Table 1 provides an overview of the explanatory variables included in the regression analysis, their expected impact on the three bank margins and the usage in previous studies investigating bank margins.

\subsubsection{Model-derived variables}

3.2.1.1. Market power. We include Lerner indices to capture banks' ability to exercise market power stemming from inelastic demand for loans and supply of deposits. As the model implies a positive influence of market power on loan and deposit margins $b^{*}$ and $a^{*}$, we expect the Lerner indices to positively influence IIM and NIM, and to negatively influence IEM.

The Lerner index measures banks' ability to attach mark-ups to the marginal cost $m c$ needed to provide a service in relation to the price $p$ charged, i.e. $(p-m c) / p$. To estimate a bank's overall market

\footnotetext{
${ }^{10}$ However, to improve interpretability, we will employ modified duration gaps instead of reverse modified duration gaps.
}

power, we estimate a single-output translog cost function dependent on three input factors (see e.g. Maudos and Fernández de Guevara, 2004; Maudos and Solís, 2009). Total assets are specified to proxy for output level. Input prices for personnel, physical and financial costs are included. Taking interest-paying liabilities as an input rather than an output is consistent with the intermediation approach of banking (Sealey and Lindley, 1977). The output price $p$ is exogenously determined and proxied as interest income in relation to interest-earning assets, and therefore identical to the IIM. ${ }^{11}$

To derive separate market power estimates for loan and deposit markets from aggregated balance sheet and income data, we follow Maudos and Fernández de Guevara (2007)'s approach and specify a two-output translog cost function. This approach is based on the Monti-Klein model of financial intermediation (Freixas and Rochet, 2008, pp. 57-59) and treats deposits as an output rather than an input. Interest-earning assets proxy for loans and interest-paying liabilities for deposits, with the ratios of interest income/interest-earning assets (IIM) and interest expenses/interest-paying liabilities (IEM) providing the two exogenously determined output prices. With liabilities being treated as outputs, only personnel and physical costs contribute to input prices.

3.2.1.2. Operating cost. Following Maudos and Fernández de Guevara (2004) and Maudos and Solís (2009), we proxy the operating cost of financial intermediation using total operating expenses/total (interest-bearing) assets (liabilities). However, it should be noted that banks' operating expenses are likely to also include costs that are due to inefficiency and those not related to activities of financial intermediation. Operating expenses are expected to have a positive influence on intermediation fees and, thus, a positive (negative) influence on IIM and NIM (IEM).

3.2.1.3. Expected excess holding period returns. Theoretically derived expected excess holding period returns cover returns from total risk transformation. However, in line with previous research, we neglect expected returns from credit risk and focus on excess holding period returns from "default-free" government bonds. Fama and French (1989) and Ilmanen (1995) provide empirical evidence that the term spread proxies expected excess holding period returns. ${ }^{12}$ Therefore, Eqs. (11) and (10) imply that loan fees $a^{*}$ are reduced and deposit fees $b^{*}$ rise when term spreads increase. This translates into expected negative effects on all three bank margins under examination.

As different banks have different maturity transformation characteristics and thus different expected excess holding period returns in their assets and liabilities, we do not use the same term spread for all banks, but calculate bank-specific term spreads. For example, given an upward-sloping yield curve, banks with a higher average loan maturity should have higher expected excess holding period returns $r_{L}-r$. To capture this effect, we calculate the duration of the interest-earning assets and the par yield of government bonds with a maturity equaling this duration. The bank-specific term spread for the assets, proxying $r_{L}-r$, is then defined as the difference between this duration-implied par yield and the 6month par yield. The liability term spread is calculated analogously and the asset-liability term spread, proxying $r_{L}-r_{D}$, is the difference between the duration-implied asset and liability par yields. The calculation of assets' and liabilities' durations is analogous to the calculation of the modified duration, described in the Internet Appendix.

\footnotetext{
11 The Internet Appendix provides further technical details.

12 See Campbell and Ammer (1993) for a theoretical justification. Alternative approaches document the power of current forward rates (Fama and Bliss, 1987) or linear combinations of forward rates (Cochrane and Piazzesi, 2005) to forecast future excess returns.
} 
Table 1

Variable description.

\begin{tabular}{|c|c|c|c|}
\hline Variable & Proxy & $\begin{array}{l}\text { Pred. coeff. } \\
\text { (IIM|IEM|NIM) }\end{array}$ & Use in other studies \\
\hline \multicolumn{4}{|l|}{ Model-derived variables } \\
\hline Market power & $\begin{array}{l}\text { Lerner index: }(p-m c) / p \text {, where total market power } \\
\text { is calculated using total assets as an output with a } \\
\text { three factor translog cost function. Loan and deposit } \\
\text { market power, however, are jointly estimated using } \\
\text { total interest-bearing assets and liabilities, } \\
\text { respectively, as output proxies and a two input factor } \\
\text { translog cost function, excluding financial cost (of } \\
\text { deposits) as in Maudos and Fernández de Guevara, } \\
2007\end{array}$ & $(+|-|+)$ & $\begin{array}{l}\text { Maudos and Fernández de Guevara (2004) and } \\
\text { Maudos and Solís (2009) }\end{array}$ \\
\hline Operating cost & $\begin{array}{l}\text { Operating expenses/total (interest-bearing) assets } \\
\text { (liabilities) }\end{array}$ & $(+|-|+)$ & $\begin{array}{l}\text { Maudos and Fernández de Guevara (2004) and } \\
\text { Maudos and Solís (2009) }\end{array}$ \\
\hline $\begin{array}{l}\text { Expected excess holding } \\
\text { period return }\end{array}$ & $\begin{array}{l}\text { Term spread: the difference between the duration } \\
\text { implied par yield and the } 6 \text {-month par yield, or } \\
\text { between asset and liability duration-implied par } \\
\text { yields for the NIM }\end{array}$ & $(-|-|-)$ & Not used up to now \\
\hline Risk aversion & $\begin{array}{l}\text { Excess capital: (regulatory capital }-0.08 \times \text { risk- } \\
\text { weighted assets)/total assets }\end{array}$ & $(+|-|+)$ & $\begin{array}{l}\text { Excess capital has not been used up to now, but is } \\
\text { proposed by Maudos and Solís (2009). Previous } \\
\text { studies use capital ratios, i.e. (regulatory) capital/ } \\
\text { total assets (McShane and Sharpe, 1985; Angbazo, } \\
\text { 1997; Brock and Suarez, 2000; Maudos and } \\
\text { Fernández de Guevara, 2004; Carbó and Rodríguez, } \\
\text { 2007; Maudos and Solís, 2009; Nguyen, 2012) }\end{array}$ \\
\hline Bank-specific IRR exposure & $\begin{array}{l}\text { Duration gap: asset duration - liability duration } \times \\
\text { interest-paying liabilities/interest-earning assets }\end{array}$ & $(++++)$ & $\begin{array}{l}\text { Not used up to now; the most similar interest rate } \\
\text { risk measure is the net position of balance sheet } \\
\text { items with a repricing period of less than one year in } \\
\text { relation to total assets (Angbazo, 1997) }\end{array}$ \\
\hline Interest rate volatility & $\begin{array}{l}\text { LIBOR volatility: annual standard deviation of the } \\
\text { weekly observed 6-month LIBOR rate }\end{array}$ & $(+|-|+)$ & $\begin{array}{l}\text { Different interest rate volatilities are used to proxy } \\
\text { for interest rate risk when explaining NIMs (Maudos } \\
\text { and Fernández de Guevara, 2004; Lepetit et al., 2008; } \\
\text { Maudos and Solís, 2009). However, these studies are } \\
\text { based on models with a single IRR source and could } \\
\text { therefore derive predictions for coefficients. }\end{array}$ \\
\hline Credit risk & Risk-weighted assets/total assets & $(+|n u|+)$ & Not used up to now \\
\hline Credit-interest covariance & $\begin{array}{l}\text { Annual correlation coefficient between the } 5 \text {-year } \\
\text { government par yield and the } 5 \text {-year credit spread on } \\
\text { corporate bonds over the } 5 \text {-year government par } \\
\text { yield }\end{array}$ & $(?|+| ?)$ & Not used up to now \\
\hline \multicolumn{4}{|l|}{ Bank-specific variables } \\
\hline Non-interest income (NII) & $\begin{array}{l}\text { Net fee income/total (interest-bearing) assets } \\
\text { (liabilities) }\end{array}$ & $(-|+|-)$ & Lepetit et al. (2008) and Maudos and Solís (2009) \\
\hline $\begin{array}{l}\text { Implicit interest payments } \\
\text { (IIP) }\end{array}$ & $\begin{array}{l}\text { (Non-interest expenses - non-interest income)/total } \\
\text { (interest-bearing) assets (liabilities) }\end{array}$ & $(+|-|+)$ & $\begin{array}{l}\text { Ho and Saunders (1981), Angbazo (1997), Saunders } \\
\text { and Schumacher (2000), Maudos and Fernández de } \\
\text { Guevara (2004), Maudos and Solís (2009) }\end{array}$ \\
\hline $\begin{array}{l}\text { Opportunity cost of reserves } \\
\text { (OCR) }\end{array}$ & $\begin{array}{l}\text { (Cash }+ \text { deposits with central banks)/total (interest- } \\
\text { bearing) assets (liabilities) }\end{array}$ & $(?|+|-)$ & \\
\hline \multicolumn{4}{|l|}{ Macroeconomic variables } \\
\hline GDP growth & Annual real GDP growth rate & $(?|?| ?)$ & $\begin{array}{l}\text { Carbó and Rodríguez (2007), Claeys and Vander } \\
\text { Vennet (2008), Albertazzi and Gambacorta (2009), } \\
\text { Maudos and Solís (2009) }\end{array}$ \\
\hline Inflation rate & Annual growth rate of consumer price index & $(?|?| ?)$ & $\begin{array}{l}\text { Demirgüç-Kunt and Huizinga (1999), Claeys and } \\
\text { Vander Vennet (2008), and Maudos and Solís (2009) }\end{array}$ \\
\hline Revolving portfolios & $\begin{array}{l}\text { Balance sheet proportion of several lender (borrower) } \\
\text { client groups and maturity brackets } \times \text { the moving } \\
\text { average of par yield government bonds }\end{array}$ & $(++\mid n u)$ & $\begin{array}{l}\text { Memmel (2008) explains interest income and ex- } \\
\text { pense margins with revolving tracking bank portfo- } \\
\text { lios }\end{array}$ \\
\hline
\end{tabular}

Total (interest-bearing) assets (liabilities) indicates that the denominator of an explanatory variable is total interest-bearing assets if the dependent variable is IIM, total interest-bearing liabilities in the case of IEM, and total assets for NIM. The following symbols are used for predicted coefficients, where the following order within brackets is given (IIM, IEM, NIM). (+) denotes an expected positive coefficient, (-) a negative coefficient, (?) that the effect cannot be predicted $a$ priori, and (nu) that the given variable is not included in a regression on the specific margin.

3.2.1.4. Risk component. For the purpose of our empirical analysis, the composite impact of the risk component will be separated into the influence of distinct variables: risk aversion, interest and credit risk.

3.2.1.4.1. Risk component-risk aversion. Most previous studies include capital ratios as proxies for risk aversion (McShane and Sharpe, 1985; Maudos and Fernández de Guevara, 2004; Maudos and Solís, 2009; Nguyen, 2012), or, without directly referring to risk aversion, as measures of insolvency risk (Angbazo, 1997; Carbó and
Rodríguez, 2007; Lepetit et al., 2008). As capital ratios do not account for differing risk levels, a point already stressed by Gambacorta and Mistrulli (2004), capital in excess of minimum regulatory requirements/total assets, or in short excess capital, generally seems to be a more adequate proxy for risk aversion. In our model, excess capital should be related to higher IIM and NIM, and lower IEM. However, the empirical study of Lepetit et al. (2008) found mixed results with both significantly positive as well as negative coefficients for different accounting margins and spreads investigated. 
3.2.1.4.2. Risk component-interest rate risk. As already discussed in Section 2, the second factor in the risk component behaves very much like a (reverse) modified duration gap. Using the detailed information on volumes and maturities of different lender and borrower types, we calculate the modified durations of the assets and liabilities, $D_{\text {mod }}^{A}$ and $D_{\text {mod }}^{L}$, respectively; then, the modified duration gap $D_{\text {gap }}$ is defined as ${ }^{13}$ :

$D_{\text {gap }}=D_{\text {mod }}^{A}-D_{\text {mod }}^{L} \frac{\text { total interest }- \text { paying liabilities }}{\text { total interest - earning assets }}$

We use the modified duration gap as an independent variable for all three margins for better comparability rather than using a reverse modified duration gap in the case of IEM. Based on our model, we expect a positive influence on all three margins.

Whereas the modified duration gap measures the overall sensitivity of a bank's net portfolio value to changes in the yield curve, it does not capture the interest rate volatility that determines the probability of changes in the yield curve. For multicollinearity reasons, we do not include separate interest volatility measures for the changes in market values of loans and deposits $\sigma_{I}$ and $\sigma_{D}$. Instead, we include just one: the annual volatility of weekly 6month LIBOR rates-measured over a 52-week window-to proxy for the risk of unexpected changes in the yield curve. The model implies that all three fees increase with higher interest rate volatility. This results in an expected positive influence on NIM and IIM, and a negative influence on IEM which is the same expected relationship as in rate-based models such as Angbazo (1997), Maudos and Fernández de Guevara (2004), and Maudos and Solís (2009). However, empirical analyses such as Gambacorta (2008) show that banks increase deposit rates with increasing interest rate volatility, which would result in a higher IEM. This suggests that Ho and Saunder-type models do not capture a specific, economically relevant relationship between deposit fees and volatility; for example, banks might decrease deposit fees to reduce the risk of withdrawals-a risk not captured in these one-period models-and to stabilize funding over more than one period in times of elevated uncertainty.

3.2.1.4.3. Risk component-credit risk. The credit risk associated with financial intermediation is integrated into the regression analysis using risk-weighted assets to total assets. While for other banks, risk-weighted assets are likely to also be associated with off-balance sheet activities and market risk, for many savings and cooperative banks they are mainly determined by the default risk of loan and bond portfolios. With deposits assumed to be default-free, the proxy is only used in regressions explaining IIM and NIM, and it is expected to have a positive impact.

3.2.1.4.4. Risk component-credit-interest risk covariance. To proxy for the covariance between credit and interest rates, we include the correlation coefficient between the 5-year government par yield and the default spread of a weighted index of corporate bonds over the 5-year government par yield. The correlation is calculated annually on the basis of weekly rates. Whereas the IIM and the NIM are determined by the correlation of both loan and deposit returns with the credit spread, the IEM is only determined by $\sigma_{C D}$. Therefore, the expected coefficient sign can only be predicted for the IEM and can be expected to increase the expenses paid by the bank.

\footnotetext{
${ }^{13}$ Details can be taken from the Internet Appendix. Angbazo (1997) uses the oneyear repricing gap, defined as the difference between assets and liabilities with a repricing frequency of less than one year to total assets (first used by Flannery and James, 1984). In our analysis, we prefer to use more detailed information on the maturities of assets and liabilities as one-year repricing gaps capture the bulk of liquidity and refinancing interest risk, but only part of the valuation risk when longterm securities are affected by interest rate changes.
}

\subsubsection{Control variables}

Previous studies investigating bank interest margins include a number of additional control variables not predicted by the model to influence the pure spread of intermediation, but to also have an impact on observed bank margins. Following these studies, we include three additional bank-specific variables as well as two macroeconomic ones. Furthermore, we control for coupon payments of fairly-priced capital market bonds as they are included in the dependent variables.

3.2.2.1. Non-interest income (NII). Past developments in banking are described as disintermediation-a shift from traditional financial intermediation to other banking activities in order to compensate for declining profitability. Carbó and Rodríguez (2007)'s model investigates cross-selling patterns between loans and non-traditional activities, which are proxied using (fee income minus fee expenses) to total (interest-bearing) assets (liabilities) (Lepetit et al., 2008). ${ }^{14}$ Cross-selling assumes that banks are willing to forego traditional interest-generating income for non-interest income (NII). Hence, the higher the NII-proxied as non-interest income to total assets-the lower the corresponding fees charged, resulting in decreasing IIM and NIM, and increasing IEM.

3.2.2.2. Implicit interest payments (IIP). We also include a proxy for implicit interest payments (IIP) using (non-interest expenses less non-interest income)/total (interest-bearing) assets (liabilities) that aims to reflect the cost of additional services for which customers have not been charged. Initially included to capture competition in the market for deposits (Ho and Saunders, 1981), it is expected to result in lower interest expenses and a negative coefficient on the related margin and a positive one on NIM. However, additional services might also be present for loans, and a positive effect on IIM might also be observed.

3.2.2.3. Opportunity cost of holding reserves (OCR). Finally, the opportunity cost of holding reserves (OCR) originates in asset portfolios that pay no remuneration, or in the case of central bank deposits in Germany, below-market rates. We include cash and deposits with central banks to total (interest-bearing) assets (liabilities) to proxy for OCR. As these reserves implicitly increase the cost of funding by foregone interest income, they are likely to be priced into deposit rates. A higher ratio of cash and deposits with central banks can therefore be expected to lead to lower interest expenses and ultimately higher net interest income; however, the effect on interest income margins remains unclear a priori.

3.2.2.4. Macroeconomic variables. Two macroeconomic variables are included: the annual real GDP growth rate controls for demand (for loans) and supply (of deposits) effects in bank profitability, and the inflation rate integrates effects of nominal contracting. For both variables, positive as well as negative coefficients are observed when investigating bank NIMs (Demirgüç-Kunt and Huizinga, 1999; Claeys and Vander Vennet, 2008; Albertazzi and Gambacorta, 2009) depending on the banking sample and time period observed, so no a priori assumption of the coefficient sign derived will be given.

3.2.2.5. Revolving portfolios. As already discussed at the beginning of Section 3.2, we have to control for fair coupon payments from

\footnotetext{
${ }^{14}$ In contrast to Lepetit et al. (2008), we do not additionally include trading activities as many smaller German banks do not generate any such income. However there is a debate in the literature about whether fee income proxies adequately for non-traditional banking activities. Therefore, we follow Nguyen (2012) and use other earning assets, defined as non-interest-bearing assets to total assets. Results are robust and remain qualitatively similar.
} 
the underlying bonds, captured in the dependent variables, to separate the effects of the fee determinants our model predicts. Since today's interest income and expenses depend on both volume as well as current and former fair market rates for different maturities we build revolving portfolios of bonds with different maturities initiated at different points in time. Since credit risk premia are controlled for by the credit risk variable, we consider default-free government bonds.

We make use of the Deutsche Bundesbank's monthly balance sheet statistics which report volumes for different lender and borrower clientele in time brackets according to the initial time to maturity. The strategy of revolving portfolios basically consists of revolvingly investing in par yield government bonds whose initial maturity depends on the respective balance sheet position's maturity bracket. We assume initial maturity is equally distributed within each bracket, each bond pays par yield when initiated and maturing bonds are replaced by new bonds of the same maturity. ${ }^{15}$ The resulting coupon payments represent weighted moving averages of par yields as shown by Memmel (2008). They are calculated for each position and time bracket and-divided by interest-earning assets, interest-paying liabilities, or total assets, respectively-they are used as control variables when investigating NIM, IIM, and IEM. ${ }^{16}$ Memmel (2008) provides empirical evidence that this approach explains much of the time series and cross-sectional variation of banks' interest income and expense margins.

\subsection{Summary statistics}

We employ a dataset of the entire German commercial banking sector, but exclude synthetic banks if (i) they lack values for one of the above-stated variables or (ii) show negative values for any balance sheet position where a negative value is not possible. When estimating non-negative marginal cost in translog cost functions, we additionally completely exclude synthetic banks whose (iii) input prices differ by more than 2.25 times the standard deviation in a given year and (iv) whose assets are less than EUR 25 million, equating to the lowest $1.5 \%$ of total assets. ${ }^{17}$ This leaves us with a total sample of 2380 (synthetic) banks, 594 of which are savings, 1730 cooperative, and 56 other banks (mainly private commercial banks). Table 2 provides summary statistics for the overall sample and the sub-samples.

There are some noteworthy features in the data, especially those highlighting differences between the sub-samples of savings and cooperative banks, and the remaining banks in the other bank sample. Average total assets are EUR 1018 million, but range from EUR 395 million for cooperative banks to EUR 9077 million for other banks. The overall sample median, however, is only EUR 329 million, which demonstrates that a huge number of small banks operate in the German banking system, whereas averages are driven by a small number of large institutions. The savings and cooperative bank samples are comparatively homogeneous in terms of size, whereas the other bank sample is much more het-

\footnotetext{
${ }^{15}$ Further details can be found in the Internet Appendix.

16 As the reported maturity brackets for assets and liabilities do not have matching maturities, we cannot create net revolving portfolios for every single bracket-used in explaining income and expenses-when analyzing the net interest margin. Therefore, in this case we create three net product group revolving portfolios by combining revolving portfolios for bank, non-bank and bond lending, and then subtracting those for borrowing. Savings accounts are added to non-bank borrowing and subordinated debt to bonds issued.

17 An exclusion based on the standard deviation of total assets-similar to the input prices-cannot be performed as total assets have an extremely skewed distribution with a mean of EUR 2.43 billion and a standard deviation of EUR 21.6 billion. Our approach assures that very small banks with high duration gaps are eliminated whereas the large banks-which are part of the other bank sample-that make up a significant proportion of the German banking system's total assets remain in our sample.
}

erogeneous. Duration gaps are higher for savings and cooperative banks, which have interest sensitivities of 0.84 and 0.9 , respectively, compared with other banks with only 0.64 . Net interest income margins range from $2.03 \%$ for savings banks and $2.48 \%$ for cooperative banks to the $2.58 \%$ observed for other banks. However, the standard deviation of NIM is more than three times higher for other banks than it is for cooperatives. The smaller savings and cooperative banks rely to a larger extent on savings deposit funding, which corresponds to $32.6 \%$ and $33.7 \%$, respectively, of total assets, whereas other banks show a quota of only $16.9 \%$. Remembering that half of the savings deposits are considered to be long-term core deposits, it is striking that savings and cooperative banks still have substantially larger duration gaps.

Other banks have the highest NIM but are less heavily involved in maturity transformation as they have the smallest duration gap. This suggests that they earn a larger fraction of their interest income through credit risk premia than through term premia. Other banks seem to assume greater credit risk, as implied by the credit risk ratios of RWA to total assets: $63.2 \%$ for other banks compared to $55.3 \%$ and $60.2 \%$ for savings and cooperative banks, respectively.

\section{Empirical analysis}

\subsection{Econometric model}

Previous studies mainly focus on an investigation of the net interest margin (NIM) as a widely used measure of commercial banks' core business profitability. ${ }^{18}$ Empirical findings are compared to the theoretical determinants derived for the pure spread. As Ho and Saunders-type models derive determinants for loan and deposit fees independently, we can test the related hypotheses for loans and deposits separately. We are the first to additionally examine the influence of the model-derived factors on the interest income margin (IIM) and the interest expense margin (IEM) separately. The reduced form regression equation of the model is given by:

$$
\begin{aligned}
B M_{i t}= & \alpha_{i}+\sum_{j=1}^{J} \beta^{j} T M_{i t}^{j}+\sum_{k=1}^{K} \gamma^{k} B S_{i t}^{k}+\sum_{l=1}^{L} \delta^{l} M E_{t}^{l}+\sum_{m=1}^{M} \eta^{m} R P_{i t}^{m} \\
& +\varepsilon_{i t}
\end{aligned}
$$

for $t=1, \ldots, T$, indicating the time period, and $i=1, \ldots, N$ as the number of banks in the sample. ${ }^{19} B M$ is the bank margin examined, either NIM, IIM, or IEM. TM refers to a vector of variables determined by the theoretical model. $B S$ is a vector of additional bank-specific control variables that are likely to influence empirically observed bank margins, but are not part of our model. ME represents macroeconomic variables with a common influence on bank margins. Finally, $R P$ represents the vector of revolving portfolios.

All regressions are estimated using fixed-effects two-stage least squares (2SLS) instrumental variables (IV) techniques, as OLS provides unbiased estimates which are, however, less efficient than GMM estimates (Wooldridge, 2001). ${ }^{20}$ Higher market power allows

\footnotetext{
${ }^{18}$ Exemptions include Carbó and Rodríguez (2007), who use a wider definition of bank margins and also include New Empirical Industrial Organizations margins, and Lepetit et al. (2008), who investigate several different definitions of bank spreads. We investigate alternative accounting margins and find robust results; see the Internet Appendix for details.

19 Ho and Saunders (1981) and Saunders and Schumacher (2000) estimate the model in a two-step procedure that aims to derive the pure spread from the first-step regressions. The pure spread is considered to be the intercept from a regression of the NIM on all factors not explicitly derived from the model. Focusing on interest risk, in our setting we prefer the single-step approach as it allows the revolving portfolios and the variables proxying for the interest risk in the intermediation fees to be correlated.

${ }^{20}$ Applying GMM yields robust results, see the Internet Appendix for details.
} 
Table 2

Summary statistics.

\begin{tabular}{|c|c|c|c|c|c|c|c|c|c|}
\hline & \multicolumn{3}{|l|}{ Full sample } & \multicolumn{2}{|c|}{ Savings banks } & \multicolumn{2}{|c|}{ Cooperative banks } & \multicolumn{2}{|c|}{ Other banks } \\
\hline & Mean & Std. dev. & Median & Mean & Std. dev. & Mean & Std. dev. & Mean & Std. dev. \\
\hline \multicolumn{10}{|l|}{ Bank size (denominators) in Emillion } \\
\hline Total interest-earning assets & 898.189 & $5,685.103$ & 290.764 & $1,767.913$ & $2,488.304$ & 350.088 & 559.547 & $8,125.128$ & $35,179.374$ \\
\hline Total interest-paying liabilities & 906.510 & $5,419.367$ & 295.307 & $1,822.069$ & $2,543.179$ & 355.553 & 593.923 & $7,714.408$ & $33,341.790$ \\
\hline Total assets (TA) & $1,017.514$ & $6,585.622$ & 328.581 & $2,019.671$ & $2,814.181$ & 394.656 & 653.023 & $9,077.482$ & $40,872.249$ \\
\hline \multicolumn{10}{|l|}{ Bank interest margins } \\
\hline Interest income margin (IIM) & 5.509 & 0.676 & 5.495 & 5.467 & 0.610 & 5.519 & 0.634 & 5.648 & 1.752 \\
\hline Interest expense margin (IEM) & 2.859 & 0.557 & 2.841 & 3.022 & 0.542 & 2.795 & 0.540 & 3.034 & 0.796 \\
\hline Net interest margin (NIM) & 2.360 & 0.530 & 2.377 & 2.027 & 0.394 & 2.473 & 0.450 & 2.582 & 1.554 \\
\hline \multicolumn{10}{|l|}{ Model-derived variables } \\
\hline Market power (loans) & 49.345 & 16.165 & 48.411 & 51.487 & 15.945 & 48.680 & 16.057 & 46.121 & 19.299 \\
\hline Market power (deposits) & -23.625 & 36.854 & -19.333 & -24.484 & 34.023 & -23.152 & 37.734 & -28.654 & 39.037 \\
\hline Market power (overall) & 37.006 & 8.830 & 37.733 & 37.879 & 7.801 & 36.766 & 8.799 & 34.729 & 16.424 \\
\hline Operating cost & 2.222 & 0.555 & 2.182 & 1.828 & 0.254 & 2.354 & 0.518 & 2.544 & 1.368 \\
\hline Term spread (asset) & 0.611 & 0.429 & 0.602 & 0.621 & 0.429 & 0.607 & 0.428 & 0.603 & 0.477 \\
\hline Term spread (liability) & 0.543 & 0.410 & 0.516 & 0.577 & 0.382 & 0.529 & 0.413 & 0.576 & 0.561 \\
\hline Term spread (asset-liability) & 0.068 & 0.439 & 0.083 & 0.044 & 0.399 & 0.078 & 0.440 & 0.027 & 0.709 \\
\hline Risk aversion & 3.203 & 1.833 & 2.844 & 2.769 & 1.475 & 3.361 & 1.856 & 3.155 & 3.324 \\
\hline Modified asset duration & 2.429 & 0.246 & 2.466 & 2.559 & 0.154 & 2.405 & 0.208 & 1.737 & 0.559 \\
\hline Modified liability duration & 1.540 & 0.223 & 1.566 & 1.651 & 0.188 & 1.512 & 0.201 & 1.169 & 0.428 \\
\hline Duration gap & 0.877 & 0.274 & 0.867 & 0.841 & 0.241 & 0.897 & 0.268 & 0.639 & 0.538 \\
\hline LIBOR volatility & 0.343 & 0.161 & 0.321 & & & & & & \\
\hline Credit risk & 59.016 & 11.520 & 60.039 & 55.258 & 11.197 & 60.233 & 11.073 & 63.174 & 17.507 \\
\hline Credit-interest covariance (correlation) & -11.488 & 12.202 & -4.879 & & & & & & \\
\hline Non-interest income (NII) & 0.667 & 0.260 & 0.636 & 0.556 & 0.111 & 0.698 & 0.239 & 0.951 & 0.878 \\
\hline Implicit interest payments (IIP) & 1.338 & 0.447 & 1.310 & 1.102 & 0.237 & 1.431 & 0.438 & 1.101 & 1.055 \\
\hline Opportunity cost of reserves (OCR) & 0.898 & 0.392 & 0.858 & 0.744 & 0.284 & 0.969 & 0.393 & 0.426 & 0.528 \\
\hline \multicolumn{10}{|l|}{ Macroeconomic variables } \\
\hline GDP growth & 0.954 & 2.124 & 1.208 & & & & & & \\
\hline Inflation rate & 1.554 & 0.695 & 1.763 & & & & & & \\
\hline \multicolumn{10}{|l|}{ Balance sheet compositions } \\
\hline Loans to banks & 11.670 & 7.581 & 10.228 & 8.333 & 5.987 & 12.649 & 7.338 & 18.469 & 14.480 \\
\hline Loans to non-banks & 60.042 & 11.825 & 61.555 & 59.541 & 12.024 & 60.253 & 11.314 & 59.095 & 21.144 \\
\hline Bonds held & 17.866 & 9.577 & 16.497 & 19.092 & 10.206 & 17.519 & 9.022 & 14.987 & 15.600 \\
\hline Loans from banks & 15.429 & 8.081 & 14.203 & 21.007 & 8.994 & 13.382 & 6.099 & 16.640 & 16.814 \\
\hline Loans from non-banks & 38.213 & 9.885 & 37.217 & 32.438 & 7.762 & 39.875 & 9.163 & 51.004 & 17.832 \\
\hline Savings deposits & 33.025 & 9.761 & 33.139 & 32.591 & 8.190 & 33.704 & 9.612 & 16.926 & 14.848 \\
\hline Subordinated debt & 0.531 & 0.964 & 0.000 & 1.317 & 1.395 & 0.249 & 0.520 & 0.524 & 0.814 \\
\hline Bonds issued & 2.714 & 3.706 & 0.846 & 2.755 & 3.030 & 2.719 & 3.896 & 2.113 & 4.413 \\
\hline
\end{tabular}

For explanatory variables calculated as quotas to total (interest-bearing) assets (liabilities), total assets are chosen for the summary statistics above. Balance sheet compositions are quotas in relation to total interest-bearing assets, or liabilities, respectively, and are used to calculate revolving portfolios by multiplying year-end values with moving averages of government par yields. All variables are displayed in percentage terms, except for the size variables used as denominators, which are denoted in $€$ million, and the duration measures. Modified asset and liability durations are not used as explanatory variables independently, but are used to calculate the duration gap, and "duration-implied" term spreads.

banks to earn higher interest margins and at the same time use the proceeds from these earnings to increase their market share. Hence, Lerner indices-which are derived using interest income and expenses in the price and marginal cost components-are likely to be endogenous, which is why we instrument Lerner indices with their own first difference. Furthermore, non-interest income (NII) might be endogenous for reasons of reversed causality, when banks are willing to grant more favorable interest conditions in order to stimulate the cross-selling of fee-generating business (Maudos and Solís, 2009). As Anderson-Rubin tests reject the hypothesis of NII being exogenous, we also instrument it with its own first difference. ${ }^{21}$ We investigate the relevance of the instruments, testing for underidentification (Kleibergen and Paap, 2006) and weak identification based on the Kleibergen-Paap F-statistic for clustered standard errors. Tests for underidentification can be rejected for all samples and all margins at convenient levels. The critical value of the Stock and Yogo (2005) weak instrument size test with two exactly identified endogenous regressors based on heteroskedastic Cragg-Donald

\footnotetext{
21 Nguyen (2012) finds that non-interest income and the NIM Granger cause each other. He corrects the arising simultaneity bias by estimating the NIM and noninterest income in a system of simultaneous equations with exogenous covariates that satisfy the exclusion restrictions.
}

statistic is 7.03. All samples except for the other bank sample, which has a far lower sample size, reject the weak instrument hypothesis. For the NIM and the IIM, the test statistics for the complete sample always display the highest value, indicating that the low statistics for the other bank sample are driven by sample size. Results are displayed for all samples, both as coefficients from level-on-level regressions and as elasticities. The coefficients for elasticities are multiplied by the factor 10 for better visibility.

\subsection{Net interest margin}

First, in line with most of the previous literature, we investigate the net interest margin and display our results in Table 3. Our interest is focused on the explanatory variables determining the pure intermediation spread (12) in our theoretical model, namely the bank's market power, operating costs, expected excess holding period returns, risk aversion, interest rate risk and credit risk, and the correlation between these two risks.

Lerner indices as a proxy for market power are highly significant and have a strong impact: an increase by $10 \%$ sends the net interest margin nearly $11 \%$ higher. This effect is especially pronounced for savings banks ( $14 \%$ increase in the NIM) and significant for all sub-samples. The higher impact of market power on 
Table 3

Determinants of net interest margin (NIM)

\begin{tabular}{|c|c|c|c|c|c|c|c|c|}
\hline & \multicolumn{2}{|c|}{ Total sample (i) } & \multicolumn{2}{|c|}{ Savings banks (ii) } & \multicolumn{2}{|c|}{ Cooperative banks (iii) } & \multicolumn{2}{|c|}{ Other banks (iv) } \\
\hline & Coeff. & Elast. & Coeff. & Elast. & Coeff. & Elast. & Coeff. & Elast. \\
\hline \multicolumn{9}{|l|}{ Model-determined variables } \\
\hline Lerner index (overall) & $\begin{array}{l}0.070^{* * *} \\
(0.0041)\end{array}$ & 10.932 & $\begin{array}{l}0.075^{* * *} \\
(0.0063)\end{array}$ & 14.076 & $\begin{array}{l}0.076^{* * *} \\
(0.0047)\end{array}$ & 11.280 & $\begin{array}{l}0.056^{* * *} \\
(0.0141)\end{array}$ & 7.599 \\
\hline Operating cost & $\begin{array}{l}1.391^{* * * *} \\
(0.1073)\end{array}$ & 13.223 & $\begin{array}{l}1.727^{* * * *} \\
(0.1845)\end{array}$ & 15.769 & $\begin{array}{l}1.618^{* * * *} \\
(0.1009)\end{array}$ & 15.560 & $\begin{array}{l}0.758^{* * * *} \\
(0.2648)\end{array}$ & 7.393 \\
\hline Term spread (asset-liability) & $\begin{array}{l}-0.041^{* * *} \\
(0.0064)\end{array}$ & -0.011 & $\begin{array}{l}-0.046^{* * *} \\
(0.0115)\end{array}$ & -0.010 & $\begin{array}{l}-0.046^{* * *} \\
(0.0070)\end{array}$ & -0.014 & $\begin{array}{l}-0.057 \\
(0.0437)\end{array}$ & -0.002 \\
\hline Excess capital & $\begin{array}{l}0.046^{* * * *} \\
(0.0051)\end{array}$ & 0.663 & $\begin{array}{l}0.098^{* * *} \\
(0.0126)\end{array}$ & 1.410 & $\begin{array}{l}0.041^{* * *} \\
(0.0047)\end{array}$ & 0.594 & $\begin{array}{l}0.036^{*} \\
(0.0200)\end{array}$ & 0.438 \\
\hline Duration gap & $\begin{array}{l}0.180^{* * *} \\
(0.0214)\end{array}$ & 0.699 & $\begin{array}{l}0.284^{* * *} \\
(0.0470)\end{array}$ & 1.215 & $\begin{array}{l}0.201^{* * *} \\
(0.0276)\end{array}$ & 0.766 & $\begin{array}{l}0.034 \\
(0.1449)\end{array}$ & 0.085 \\
\hline LIBOR volatility & $\begin{array}{l}1.014^{* * *} \\
(0.0712)\end{array}$ & 1.520 & $\begin{array}{l}1.168^{* * * *} \\
(0.1238)\end{array}$ & 2.040 & $\begin{array}{l}1.080^{* * * *} \\
(0.0770)\end{array}$ & 1.542 & $\begin{array}{l}0.861^{* * * *} \\
(0.2323)\end{array}$ & 1.168 \\
\hline Credit risk & $\begin{array}{l}0.007^{* * *} \\
(0.0006)\end{array}$ & 1.772 & $\begin{array}{l}0.007^{* * *} \\
(0.0014)\end{array}$ & 1.862 & $\begin{array}{l}0.007^{* * *} \\
(0.0007)\end{array}$ & 1.783 & $\begin{array}{l}0.005 \\
(0.0039)\end{array}$ & 1.315 \\
\hline Credit-interest covariance & $\begin{array}{l}0.028^{* * * *} \\
(0.0021)\end{array}$ & 1.021 & $\begin{array}{l}0.030^{* * * *} \\
(0.0030)\end{array}$ & 1.302 & $\begin{array}{l}0.032^{\text {***** }} \\
(0.0024)\end{array}$ & 1.119 & $\begin{array}{l}0.019^{* * * *} \\
(0.0068)\end{array}$ & 0.636 \\
\hline \multicolumn{9}{|l|}{ Bank-specific variables } \\
\hline NII & $\begin{array}{l}-1.357^{* * *} \\
(0.1505)\end{array}$ & -3.889 & $\begin{array}{l}-3.347^{* * *} \\
(0.4140)\end{array}$ & -9.392 & $\begin{array}{l}-1.548^{* * *} \\
(0.1252)\end{array}$ & -4.427 & $\begin{array}{l}-0.430 \\
(0.3414)\end{array}$ & -1.557 \\
\hline IIP & $\begin{array}{l}-0.458^{* * * *} \\
(0.0639)\end{array}$ & -2.603 & $\begin{array}{l}-0.585^{* * *} \\
(0.1161)\end{array}$ & -3.194 & $\begin{array}{l}-0.623^{* * *} \\
(0.0606)\end{array}$ & -3.614 & $\begin{array}{l}-0.027 \\
(0.1491)\end{array}$ & -0.118 \\
\hline OCR & $\begin{array}{l}0.003 \\
(0.0103)\end{array}$ & 0.013 & $\begin{array}{l}-0.010 \\
(0.0248)\end{array}$ & -0.038 & $\begin{array}{l}0.019 \\
(0.0129)\end{array}$ & 0.076 & $\begin{array}{l}-0.037 \\
(0.1442)\end{array}$ & -0.058 \\
\hline \multicolumn{9}{|l|}{ Macroeconomic variables } \\
\hline GDP growth & $\begin{array}{l}-0.118^{* * *} \\
(0.0106)\end{array}$ & -0.478 & $\begin{array}{l}-0.091^{* * *} \\
(0.0109)\end{array}$ & -0.421 & $\begin{array}{l}-0.154^{* * *} \\
(0.0133)\end{array}$ & -0.595 & $\begin{array}{l}-0.066^{* *} \\
(0.0267)\end{array}$ & -0.257 \\
\hline Inflation rate & $\begin{array}{l}0.620^{* * * *} \\
(0.0478)\end{array}$ & 4.368 & $\begin{array}{l}0.654^{* * *} \\
(0.0686)\end{array}$ & 5.364 & $\begin{array}{l}0.723^{* * *} \\
(0.0552)\end{array}$ & 4.850 & $\begin{array}{l}0.456^{* * *} \\
(0.1496)\end{array}$ & 2.879 \\
\hline \multicolumn{9}{|l|}{ Revolving portfolios } \\
\hline Net loans to/from banks & $\begin{array}{l}0.007 \\
(0.0295)\end{array}$ & 0.008 & $\begin{array}{l}0.133^{* * *} \\
(0.0348)\end{array}$ & 0.393 & $\begin{array}{l}-0.078^{* *} \\
(0.0343)\end{array}$ & -0.037 & $\begin{array}{l}0.110 \\
(0.0955)\end{array}$ & 0.022 \\
\hline Net business to/from non-banks & $\begin{array}{l}-0.044^{* * *} \\
(0.0204)\end{array}$ & -0.008 & $\begin{array}{l}0.047^{* *} \\
(0.0204)\end{array}$ & 0.057 & $\begin{array}{l}-0.123^{\text {**** }} \\
(0.0267)\end{array}$ & -0.074 & $\begin{array}{l}0.120^{*} \\
(0.0658)\end{array}$ & 0.121 \\
\hline Net bond portfolios & $\begin{array}{l}-0.127^{* * *} \\
(0.0377)\end{array}$ & -0.380 & $\begin{array}{l}-0.219^{* * *} \\
(0.0603)\end{array}$ & -0.849 & $\begin{array}{l}-0.175^{\text {*** }} \\
(0.0414)\end{array}$ & -0.481 & $\begin{array}{l}-0.025 \\
(0.1201)\end{array}$ & -0.056 \\
\hline Obs. & 16,396 & & 4479 & & 11,524 & & 393 & \\
\hline Number of synthetic banks & 2380 & & 594 & & 1730 & & 56 & \\
\hline$G R^{2}$ & 0.536 & & 0.459 & & 0.592 & & 0.382 & \\
\hline Underid. LM stat. [p-value] & 71.18 & {$[0]$} & 40.48 & {$[0]$} & 52.91 & {$[0]$} & 7.459 & {$[0.006]$} \\
\hline Kleibergen-Paap F-test & 58.23 & & 30.28 & & 43.55 & & 5.405 & \\
\hline
\end{tabular}

Dependent variable: net interest margin (NIM). Operating cost, non-interest income (NII), opportunity cost of reserves (OCR) and implicit interest payments (IIP) are in relation to total assets. All models are estimated using fixed-effects 2SLS IV regressions, where Lerner index (overall) and NII are instrumented with their own first differences. Underid. gives the LM statistic and the $p$-value for the Kleibergen and Paap (2006) rank test of underidentification. Kleibergen-Paap F-test is the weak instrument statistic for clustered standard errors. Elasticities of variables are displayed on the right next to coefficients and are calculated at sample mean and multiplied by the factor 10 . Elasticities are estimated using chain rules, and are multiplied by -10 if evaluated at a negative sample mean. Standard errors are given in parentheses and are clustered at bank level. $G R^{2}$ is the generalized $R^{2}$ criterion of Pesaran and Smith (1994) for 2SLS IV estimation.

* Significance at the $10 \%$ level.

** Significance at the $5 \%$ level.

*** Significance at the $1 \%$ level.

the NIM underlines the fact that many rural savings and cooperative banks only face competition from a single bank of the other pillar as these banks operate in delimited regions and only have a few branches of private commercial banks in their area, allowing them to charge higher fees.

The operating costs are highly significant as well. The positive sign of the coefficients is in line with the model predictions, and the magnitude of the coefficients is economically relevant: an increase by 100 basis points in operating costs translates into an increase of 139 basis points in the NIM; for savings banks the increase amounts to as much as 173 basis points.

Regarding the term spread included as an instrument for expected returns from maturity transformation, we find the expected negative coefficients. The coefficient is significant for savings and cooperative banks, though it is even larger for other banks. From an economic point of view, the results confirm that banks pass part of the expected holding period returns to customers during times when an increasing yield curve, controlled for with revolving portfolios, generates earnings from maturity transformation. However, this effect is economically not very relevant: a roughly 4-6 basis point reduction in fees for a 100 basis point change in the term spread.

In a similar vein, the interest risk proxies also have to be interpreted as additional net fee income. In line with our expectations, we find that savings and cooperative banks earn significant extra charges of 28 and 20 basis points for each additional percentage point of interest sensitivity resulting from a positive maturity gap. Other banks, by contrast, have a coefficient close to zero, so that a significant impact can be rejected for more than solely small sample size. Similar results are reported for U.S. banks by Angbazo (1997), who finds the one-year repricing gap to be related exclusively to smaller regional banks' NIMs, but not to larger money 
Table 4

Determinants of interest income margin (IIM).

\begin{tabular}{|c|c|c|c|c|c|c|c|c|}
\hline & \multicolumn{2}{|c|}{ Total sample (i) } & \multicolumn{2}{|c|}{ Savings banks (ii) } & \multicolumn{2}{|c|}{ Cooperative banks (iii) } & \multicolumn{2}{|c|}{ Other banks (iv) } \\
\hline & Coeff. & Elast. & Coeff. & Elast. & Coeff. & Elast. & Coeff. & Elast. \\
\hline \multicolumn{9}{|l|}{ Model-determined variables } \\
\hline Lerner index (assets) & $\begin{array}{l}0.051^{* * *} \\
(0.0031)\end{array}$ & 4.680 & $\begin{array}{l}0.044^{* * *} \\
(0.0045)\end{array}$ & 4.204 & $\begin{array}{l}0.056^{* * *} \\
(0.0048)\end{array}$ & 5.042 & $\begin{array}{l}0.065^{* * *} \\
(0.0115)\end{array}$ & 5.338 \\
\hline Operating cost & $\begin{array}{l}-0.083^{*} \\
(0.0478)\end{array}$ & -0.381 & $\begin{array}{l}0.100 \\
(0.1269)\end{array}$ & 0.391 & $\begin{array}{l}-0.032 \\
(0.0268)\end{array}$ & -0.154 & $\begin{array}{l}-0.161 \\
(0.2421)\end{array}$ & -0.787 \\
\hline Term spread (asset) & $\begin{array}{l}-0.155^{* * *} \\
(0.0175)\end{array}$ & -0.153 & $\begin{array}{l}-0.090^{* * * *} \\
(0.0217)\end{array}$ & -0.092 & $\begin{array}{l}-0.155^{* * *} \\
(0.0251)\end{array}$ & -0.152 & $\begin{array}{l}-0.168^{*} \\
(0.0860)\end{array}$ & -0.164 \\
\hline Excess capital & $\begin{array}{l}0.046^{* * * *} \\
(0.0056)\end{array}$ & 0.287 & $\begin{array}{l}0.039^{* * *} \\
(0.0076)\end{array}$ & 0.208 & $\begin{array}{l}0.060^{* * * *} \\
(0.0075)\end{array}$ & 0.394 & $\begin{array}{l}-0.006 \\
(0.0219)\end{array}$ & -0.034 \\
\hline Duration gap & $\begin{array}{l}0.337^{* * *} \\
(0.0505)\end{array}$ & 0.564 & $\begin{array}{l}0.370^{* * *} \\
(0.0673)\end{array}$ & 0.588 & $\begin{array}{l}0.567^{* * *} \\
(0.0715)\end{array}$ & 0.976 & $\begin{array}{l}-0.046 \\
(0.1335)\end{array}$ & -0.054 \\
\hline LIBOR volatility & $\begin{array}{l}1.501^{* * *} \\
(0.1049)\end{array}$ & 0.967 & $\begin{array}{l}0.993^{* * *} \\
(0.1227)\end{array}$ & 0.644 & $\begin{array}{l}1.445^{* * *} \\
(0.1346)\end{array}$ & 0.930 & $\begin{array}{l}1.671^{* * *} \\
(0.2797)\end{array}$ & 1.045 \\
\hline Credit risk & $\begin{array}{l}0.020^{* * *} \\
(0.0017)\end{array}$ & 2.178 & $\begin{array}{l}0.020^{* * *} \\
(0.0021)\end{array}$ & 2.070 & $\begin{array}{l}0.017^{* * *} \\
(0.0015)\end{array}$ & 1.927 & $\begin{array}{l}0.019^{* *} \\
(0.0095)\end{array}$ & 2.193 \\
\hline Credit-interest covariance & $\begin{array}{l}-0.010^{* * *} \\
(0.0004)\end{array}$ & -0.150 & $\begin{array}{l}-0.009^{* * *} \\
(0.0006)\end{array}$ & -0.144 & $\begin{array}{l}-0.009^{\text {**** }} \\
(0.0004)\end{array}$ & -0.138 & $\begin{array}{l}-0.014^{* * *} \\
(0.0031)\end{array}$ & -0.217 \\
\hline \multicolumn{9}{|l|}{ Bank-specific variables } \\
\hline NII & $\begin{array}{l}0.570^{* * *} \\
(0.0879)\end{array}$ & 0.793 & $\begin{array}{l}1.250^{* * *} \\
(0.3546)\end{array}$ & 1.509 & $\begin{array}{l}0.427^{* * *} \\
(0.0812)\end{array}$ & 0.618 & $\begin{array}{l}0.618^{*} \\
(0.3514)\end{array}$ & 1.132 \\
\hline IIP & $\begin{array}{l}0.239^{* * *} \\
(0.0332)\end{array}$ & 0.656 & $\begin{array}{l}0.152^{*} \\
(0.0778)\end{array}$ & 0.355 & $\begin{array}{l}0.184^{* * *} \\
(0.0189)\end{array}$ & 0.536 & $\begin{array}{l}0.404^{* *} \\
(0.2005)\end{array}$ & 0.877 \\
\hline OCR & $\begin{array}{l}0.101^{* * *} \\
(0.0124)\end{array}$ & 0.186 & $\begin{array}{l}0.118^{* * *} \\
(0.0317)\end{array}$ & 0.188 & $\begin{array}{l}0.099^{* * *} \\
(0.0156)\end{array}$ & 0.196 & $\begin{array}{l}-0.145 \\
(0.1259)\end{array}$ & -0.114 \\
\hline \multicolumn{9}{|l|}{ Macroeconomic variables } \\
\hline GDP growth & $\begin{array}{l}0.081^{* * *} \\
(0.0063)\end{array}$ & 0.140 & $\begin{array}{l}0.055^{* * *} \\
(0.0097)\end{array}$ & 0.095 & $\begin{array}{l}0.098^{* * *} \\
(0.0092)\end{array}$ & 0.171 & $\begin{array}{l}0.126^{* * *} \\
(0.0323)\end{array}$ & 0.227 \\
\hline Inflation rate & $\begin{array}{l}0.283^{* * * *} \\
(0.0233)\end{array}$ & 0.856 & $\begin{array}{l}0.250^{* * * *} \\
(0.0315)\end{array}$ & 0.760 & $\begin{array}{l}0.265^{* * * *} \\
(0.0326)\end{array}$ & 0.801 & $\begin{array}{l}0.235^{* * * *} \\
(0.0721)\end{array}$ & 0.683 \\
\hline \multicolumn{9}{|l|}{$\begin{array}{l}\text { Revolving portfolios } \\
\text { Loans to banks }\end{array}$} \\
\hline daily & $\begin{array}{l}2.208^{* * * *} \\
(0.1171)\end{array}$ & 0.589 & $\begin{array}{l}2.207^{* * * *} \\
(0.1460)\end{array}$ & 0.320 & $\begin{array}{l}2.465^{* * * *} \\
(0.1744)\end{array}$ & 0.762 & $\begin{array}{l}2.120^{* * * *} \\
(0.3395)\end{array}$ & 0.793 \\
\hline$\leqslant 1 \mathrm{y}$ & $\begin{array}{l}1.976^{* * *} \\
(0.0997)\end{array}$ & 0.454 & $\begin{array}{l}2.042^{* * *} \\
(0.1340)\end{array}$ & 0.530 & $\begin{array}{l}2.112^{* * *} \\
(0.1425)\end{array}$ & 0.434 & $\begin{array}{l}1.828^{* * *} \\
(0.2509)\end{array}$ & 1.126 \\
\hline$>1 \mathrm{y} . \leqslant 5 \mathrm{y}$ & $\begin{array}{l}1.626^{* * * *} \\
(0.0706)\end{array}$ & 0.278 & $\begin{array}{l}1.680^{* * * *} \\
(0.1082)\end{array}$ & 0.124 & $\begin{array}{l}1.717^{* * * *} \\
(0.0996)\end{array}$ & 0.362 & $\begin{array}{l}1.784^{* * * *} \\
(0.4567)\end{array}$ & 0.124 \\
\hline$>5 \mathrm{y}$ & $\begin{array}{l}1.217^{* * *} \\
(0.0518)\end{array}$ & 0.199 & $\begin{array}{l}1.310^{* * *} \\
(0.0805)\end{array}$ & 0.194 & $\begin{array}{l}1.229^{* * *} \\
(0.0642)\end{array}$ & 0.212 & $\begin{array}{l}1.028^{* * *} \\
(0.3521)\end{array}$ & 0.078 \\
\hline \multicolumn{9}{|l|}{ Loans to non-banks } \\
\hline$\leqslant 1 \mathrm{y}$ & $\begin{array}{l}2.162^{* * *} \\
(0.1653)\end{array}$ & 1.052 & $\begin{array}{l}3.012^{* * *} \\
(0.2245)\end{array}$ & 1.338 & $\begin{array}{l}2.750^{* * *} \\
(0.1546)\end{array}$ & 1.312 & $\begin{array}{l}1.505^{* * *} \\
(0.2596)\end{array}$ & 1.836 \\
\hline$>1 \mathrm{y} . \leqslant 5 \mathrm{y}$ & $\begin{array}{l}1.551^{* * *} \\
(0.0647)\end{array}$ & 0.615 & $\begin{array}{l}1.590^{* * *} \\
(0.1441)\end{array}$ & 0.399 & $\begin{array}{l}1.636^{* * *} \\
(0.0699)\end{array}$ & 0.711 & $\begin{array}{l}1.243^{* * *} \\
(0.2858)\end{array}$ & 1.131 \\
\hline$>5 \mathrm{y}$ & $\begin{array}{l}1.120^{* * * *} \\
(0.0252)\end{array}$ & 4.942 & $\begin{array}{l}1.015^{* * * *} \\
(0.0303)\end{array}$ & 4.866 & $\begin{array}{l}1.089^{* * * *} \\
(0.0263)\end{array}$ & 4.721 & $\begin{array}{l}1.185^{* * * *} \\
(0.2162)\end{array}$ & 2.806 \\
\hline \multicolumn{9}{|l|}{ Bonds held } \\
\hline$\leqslant 1 \mathrm{y}$ & $\begin{array}{l}0.778^{* * *} \\
(0.0894)\end{array}$ & 0.011 & $\begin{array}{l}1.002^{* * *} \\
(0.1451)\end{array}$ & 0.016 & $\begin{array}{l}0.782^{* * * *} \\
(0.1002)\end{array}$ & 0.011 & $\begin{array}{l}-1.651 \\
(1.1166)\end{array}$ & -0.016 \\
\hline$>1 \mathrm{y} . \leqslant 2 \mathrm{y}$ & $\begin{array}{l}0.974^{* * *} \\
(0.0629)\end{array}$ & 0.043 & $\begin{array}{l}1.155^{* * * *} \\
(0.0762)\end{array}$ & 0.062 & $\begin{array}{l}1.077^{* * * *} \\
(0.0771)\end{array}$ & 0.044 & $\begin{array}{l}0.669 \\
(0.5095)\end{array}$ & 0.039 \\
\hline$>2 \mathrm{y}$ & $\begin{array}{l}0.607^{* * * *} \\
(0.0221)\end{array}$ & 0.883 & $\begin{array}{l}0.765^{* * *} \\
(0.0486)\end{array}$ & 1.222 & $\begin{array}{l}0.570^{* * *} \\
(0.0239)\end{array}$ & 0.805 & $\begin{array}{l}0.316^{* *} \\
(0.1360)\end{array}$ & 0.351 \\
\hline Obs. & 16,396 & & 4479 & & 11,524 & & 393 & \\
\hline Number of synthetic banks & 2380 & & 594 & & 1730 & & 56 & \\
\hline$G R^{2}$ & 0.866 & & 0.896 & & 0.890 & & 0.648 & \\
\hline Underid. LM stat. [p-value] & 92.89 & {$[0]$} & 52.59 & {$[0]$} & 48.90 & {$[0]$} & 7.764 & {$[0.005]$} \\
\hline Kleibergen-Paap F-test & 118.4 & & 70.15 & & 48.20 & & 5.191 & \\
\hline
\end{tabular}

Dependent variable: interest income margin (IIM). Operating cost, non-interest income (NII), opportunity cost of reserves (OCR) and implicit interest payments (IIP) are in relation to interest-earning assets. All models are estimated using fixed-effects 2SLS IV regressions, where Lerner index (assets) and NII are instrumented with their own first differences. Underid. gives the LM statistic and the $p$-value for the Kleibergen and Paap (2006) rank test of underidentification. Kleibergen-Paap $F$-test is the weak instrument statistic for clustered standard errors. Elasticities of variables are displayed on the right next to coefficients and are calculated at sample mean and multiplied by the factor 10 . Elasticities are estimated using chain rules, and are multiplied by -10 if evaluated at a negative sample mean. Standard errors are given in parentheses and are clustered at bank level. $G R^{2}$ is the generalized $R^{2}$ criterion of Pesaran and Smith (1994) for 2SLS IV estimation.

* Significance at the $10 \%$ level.

** Significance at the 5\% level.

*** Significance at the $1 \%$ level. 
Table 5

Determinants of the interest expense margin (IEM)

\begin{tabular}{|c|c|c|c|c|c|c|c|c|}
\hline & \multicolumn{2}{|c|}{ Total sample (i) } & \multicolumn{2}{|c|}{ Savings banks (ii) } & \multicolumn{2}{|c|}{ Cooperative banks (iii) } & \multicolumn{2}{|c|}{ Other banks (iv) } \\
\hline & Coeff. & Elast. & Coeff. & Elast. & Coeff. & Elast. & Coeff. & Elast. \\
\hline \multicolumn{9}{|l|}{ Model-determined variables } \\
\hline Lerner index (deposits) & $\begin{array}{l}-0.010^{* * *} \\
(0.0005)\end{array}$ & -0.822 & $\begin{array}{l}-0.014^{* * * *} \\
(0.0008)\end{array}$ & -1.122 & $\begin{array}{l}-0.008^{* * *} \\
(0.0004)\end{array}$ & -0.704 & $\begin{array}{l}-0.019^{* * *} \\
(0.0035)\end{array}$ & -1.792 \\
\hline Operating cost & $\begin{array}{l}-0.190^{* * * *} \\
(0.0358)\end{array}$ & -1.679 & $\begin{array}{l}-0.388^{* * * *} \\
(0.0536)\end{array}$ & -2.649 & $\begin{array}{l}-0.209^{* * * *} \\
(0.0152)\end{array}$ & -2.018 & $\begin{array}{l}-0.042 \\
(0.2087)\end{array}$ & -0.418 \\
\hline Term spread (liabilities) & $\begin{array}{l}0.010^{* *} \\
(0.0049)\end{array}$ & 0.017 & $\begin{array}{l}0.009 \\
(0.0085)\end{array}$ & 0.016 & $\begin{array}{l}0.022^{* * * *} \\
(0.0050)\end{array}$ & 0.037 & $\begin{array}{l}0.017 \\
(0.0467)\end{array}$ & 0.030 \\
\hline Excess capital & $\begin{array}{l}-0.001 \\
(0.0029)\end{array}$ & -0.016 & $\begin{array}{l}0.014^{* * *} \\
(0.0053)\end{array}$ & 0.135 & $\begin{array}{l}-0.002 \\
(0.0026)\end{array}$ & -0.026 & $\begin{array}{l}-0.035^{\text {**** }} \\
(0.0114)\end{array}$ & -0.366 \\
\hline Duration gap & $\begin{array}{l}0.042^{\text {*** }} \\
(0.0177)\end{array}$ & 0.135 & $\begin{array}{l}0.012 \\
(0.0293)\end{array}$ & 0.035 & $\begin{array}{l}0.082^{* * *} \\
(0.0188)\end{array}$ & 0.280 & $\begin{array}{l}0.005 \\
(0.1204)\end{array}$ & 0.011 \\
\hline LIBOR volatility & $\begin{array}{l}0.125^{* * *} \\
(0.0147)\end{array}$ & 0.156 & $\begin{array}{l}0.097^{* * * *} \\
(0.0220)\end{array}$ & 0.114 & $\begin{array}{l}0.111^{* * * *} \\
(0.0143)\end{array}$ & 0.142 & $\begin{array}{l}0.091 \\
(0.1442)\end{array}$ & 0.107 \\
\hline Credit-interest covariance & $\begin{array}{l}-0.006^{* * *} \\
(0.0003)\end{array}$ & -0.186 & $\begin{array}{l}-0.006^{* * *} \\
(0.0003)\end{array}$ & -0.181 & $\begin{array}{l}-0.006^{* * * *} \\
(0.0002)\end{array}$ & -0.192 & $\begin{array}{l}-0.012^{* * * *} \\
(0.0028)\end{array}$ & -0.333 \\
\hline \multicolumn{9}{|l|}{ Bank-specific variables } \\
\hline NII & $\begin{array}{l}0.365^{* * *} \\
(0.0858)\end{array}$ & 0.976 & $\begin{array}{l}1.252^{* * *} \\
(0.1368)\end{array}$ & 2.627 & $\begin{array}{l}0.397^{* * *} \\
(0.0348)\end{array}$ & 1.140 & $\begin{array}{l}-0.039 \\
(0.3519)\end{array}$ & -0.143 \\
\hline IIP & $\begin{array}{l}0.050^{* *} \\
(0.0198)\end{array}$ & 0.265 & $\begin{array}{l}0.135^{* * *} \\
(0.0430)\end{array}$ & 0.552 & $\begin{array}{l}0.048^{* * *} \\
(0.0108)\end{array}$ & 0.279 & $\begin{array}{l}-0.028 \\
(0.1570)\end{array}$ & -0.122 \\
\hline OCR & $\begin{array}{l}-0.034^{* * *} \\
(0.0076)\end{array}$ & -0.120 & $\begin{array}{l}-0.010 \\
(0.0144)\end{array}$ & -0.028 & $\begin{array}{l}-0.038^{* * *} \\
(0.0071)\end{array}$ & -0.149 & $\begin{array}{l}-0.065 \\
(0.0734)\end{array}$ & -0.103 \\
\hline \multicolumn{9}{|l|}{ Macroeconomic variables } \\
\hline GDP growth & $\begin{array}{l}0.007^{* *} \\
(0.0034)\end{array}$ & 0.024 & $\begin{array}{l}0.006 \\
(0.0052)\end{array}$ & 0.020 & $\begin{array}{l}0.003 \\
(0.0030)\end{array}$ & 0.011 & $\begin{array}{l}0.092^{* * *} \\
(0.0322)\end{array}$ & 0.309 \\
\hline Inflation rate & $\begin{array}{l}-0.022^{* * *} \\
(0.0062)\end{array}$ & -0.128 & $\begin{array}{l}0.020^{* * *} \\
(0.0075)\end{array}$ & 0.109 & $\begin{array}{l}-0.043^{* * *} \\
(0.0051)\end{array}$ & -0.262 & $\begin{array}{l}0.007 \\
(0.0483)\end{array}$ & 0.036 \\
\hline \multicolumn{9}{|l|}{$\begin{array}{l}\text { Revolving portfolios } \\
\text { Loans from banks }\end{array}$} \\
\hline daily & $\begin{array}{l}0.889^{* * *} \\
(0.0504)\end{array}$ & 0.049 & $\begin{array}{l}1.076^{* * *} \\
(0.0659)\end{array}$ & 0.107 & $\begin{array}{l}0.813^{* * *} \\
(0.0687)\end{array}$ & 0.025 & $\begin{array}{l}0.836^{* * *} \\
(0.1828)\end{array}$ & 0.172 \\
\hline$\leqslant 1 \mathrm{y}$ & $\begin{array}{l}0.798^{* * *} \\
(0.0693)\end{array}$ & 0.126 & $\begin{array}{l}0.906^{* * *} \\
(0.0408)\end{array}$ & 0.248 & $\begin{array}{l}0.657^{* * *} \\
(0.0429)\end{array}$ & 0.058 & $\begin{array}{l}1.201^{* * *} \\
(0.1346)\end{array}$ & 0.877 \\
\hline$>1 \mathrm{y} . \leqslant 2 \mathrm{y}$ & $\begin{array}{l}0.671^{* * *} \\
(0.0576)\end{array}$ & 0.022 & $\begin{array}{l}0.733^{* * *} \\
(0.0946)\end{array}$ & 0.028 & $\begin{array}{l}0.563^{* * *} \\
(0.0762)\end{array}$ & 0.016 & $\begin{array}{l}1.174^{* * * *} \\
(0.2031)\end{array}$ & 0.121 \\
\hline$>2 \mathrm{y}$ & $\begin{array}{l}0.869 * * * \\
(0.0246)\end{array}$ & 1.938 & $\begin{array}{l}0.975 * * * \\
(0.0271)\end{array}$ & 2.639 & $\begin{array}{l}0.919 * * * \\
(0.0215)\end{array}$ & 1.902 & $\begin{array}{l}1.014^{* * * *} \\
(0.1108)\end{array}$ & 1.287 \\
\hline $\begin{array}{l}\text { Loans from non-banks } \\
\text { daily }\end{array}$ & $\begin{array}{l}0.848^{* * * *} \\
(0.0327)\end{array}$ & 2.013 & $\begin{array}{l}1.177^{* * * *} \\
(0.0538)\end{array}$ & 2.475 & $\begin{array}{l}0.761^{* * *} \\
(0.0299)\end{array}$ & 1.887 & $\begin{array}{l}1.061^{* * *} \\
(0.1609)\end{array}$ & 2.698 \\
\hline$\leqslant 1 \mathrm{y}$ & $\begin{array}{l}0.971^{* * *} \\
(0.0209)\end{array}$ & 1.363 & $\begin{array}{l}1.040^{* * *} \\
(0.0434)\end{array}$ & 0.880 & $\begin{array}{l}0.926 * * * \\
(0.0192)\end{array}$ & 1.479 & $\begin{array}{l}1.217^{* * * *} \\
(0.1401)\end{array}$ & 2.961 \\
\hline$>1 \mathrm{y} . \leqslant 2 \mathrm{y}$ & $\begin{array}{l}1.045^{* * *} \\
(0.0474)\end{array}$ & 0.226 & $\begin{array}{l}1.113^{* * *} \\
(0.0961)\end{array}$ & 0.131 & $\begin{array}{l}0.973 * * * \\
(0.0434)\end{array}$ & 0.250 & $\begin{array}{l}1.198^{* * *} \\
(0.3650)\end{array}$ & 0.259 \\
\hline$>2 \mathrm{y}$ & $\begin{array}{l}0.848^{* * *} \\
(0.0396)\end{array}$ & 0.823 & $\begin{array}{l}0.914^{* * *} \\
(0.0464)\end{array}$ & 0.792 & $\begin{array}{l}0.839^{* * *} \\
(0.0306)\end{array}$ & 0.840 & $\begin{array}{l}0.867^{* * *} \\
(0.1307)\end{array}$ & 1.132 \\
\hline Subordinated debt & $\begin{array}{l}0.908^{* * *} \\
(0.1238)\end{array}$ & 0.079 & $\begin{array}{l}0.498^{* * *} \\
(0.1336)\end{array}$ & 0.099 & $\begin{array}{l}1.938^{* * *} \\
(0.2632)\end{array}$ & 0.078 & $\begin{array}{l}1.375 \\
(1.2662)\end{array}$ & 0.113 \\
\hline $\begin{array}{l}\text { Savings accounts } \\
\leqslant 3 \mathrm{~m} .\end{array}$ & $\begin{array}{l}0.809 * * * \\
(0.0164)\end{array}$ & 3.550 & $\begin{array}{l}0.927^{* * *} \\
(0.0290)\end{array}$ & 3.561 & $\begin{array}{l}0.782^{* * *} \\
(0.0152)\end{array}$ & 3.674 & $\begin{array}{l}0.891^{* * *} \\
(0.1052)\end{array}$ & 1.893 \\
\hline$>3 \mathrm{~m}$ & $\begin{array}{l}0.777^{* * *} \\
(0.0182)\end{array}$ & 0.760 & $\begin{array}{l}0.905^{* * *} \\
(0.0318)\end{array}$ & 1.039 & $\begin{array}{l}0.752^{* * *} \\
(0.0199)\end{array}$ & 0.693 & $\begin{array}{l}0.956^{* * *} \\
(0.1703)\end{array}$ & 0.582 \\
\hline $\begin{array}{l}\text { Bonds issued } \\
\leqslant 1 \mathrm{y}\end{array}$ & $\begin{array}{l}0.143 \\
(0.1977)\end{array}$ & 0.001 & $\begin{array}{l}-0.140 \\
(0.2632)\end{array}$ & -0.001 & $\begin{array}{l}0.300 \\
(0.3571)\end{array}$ & 0.001 & $\begin{array}{l}0.591 \\
(1.0066)\end{array}$ & 0.008 \\
\hline$>1 \mathrm{y} . \leqslant 2 \mathrm{y}$ & $\begin{array}{l}0.213^{* *} \\
(0.0918)\end{array}$ & 0.007 & $\begin{array}{l}0.058 \\
(0.1608)\end{array}$ & 0.002 & $\begin{array}{l}0.265^{* * * *} \\
(0.0999)\end{array}$ & 0.009 & $\begin{array}{l}1.231 \\
(1.5459)\end{array}$ & 0.023 \\
\hline$>2 \mathrm{y}$ & $\begin{array}{l}0.437^{* * *} \\
(0.0424) \\
\end{array}$ & 0.175 & $\begin{array}{l}0.400^{* * * *} \\
(0.0707) \\
\end{array}$ & 0.147 & $\begin{array}{l}0.521^{* * * *} \\
(0.0439) \\
\end{array}$ & 0.219 & $\begin{array}{l}0.903^{*} \\
(0.4808) \\
\end{array}$ & 0.229 \\
\hline Obs. & 16,396 & & 4479 & & 11,524 & & 393 & \\
\hline Number of synthetic banks & 2380 & & 594 & & 1730 & & 56 & \\
\hline$G R^{2}$ & 0.869 & & 0.882 & & 0.883 & & 0.787 & \\
\hline $\begin{array}{l}\text { Underid. LM stat. [p-value] } \\
\text { Kleibergen-Paap F-test }\end{array}$ & $\begin{array}{l}98.66 \\
88.79\end{array}$ & {$[0]$} & $\begin{array}{l}207.5 \\
218.3\end{array}$ & {$[0]$} & $\begin{array}{l}606.3 \\
2516\end{array}$ & [0] & $\begin{array}{l}7.966 \\
5.619\end{array}$ & [0.005] \\
\hline
\end{tabular}

Dependent variable: interest expense margin (IEM). Operating cost, non-interest income (NII), opportunity cost of reserves (OCR) and implicit interest payments (IIP) are in relation to interest-paying liabilities. All models are estimated using fixed-effects 2SLS IV regressions, where Lerner index (deposits) and NII are instrumented with their own first differences. Underid. gives the LM statistic and the $p$-value for the Kleibergen and Paap (2006) rank test of underidentification. Kleibergen-Paap F-test is the weak instrument statistic for clustered standard errors. Elasticities of variables are displayed on the right next to coefficients and are calculated at sample mean and multiplied by the factor 10. Elasticities are estimated using chain rules, and are multiplied by -10 if evaluated at a negative sample mean. Standard errors are given in parentheses and are clustered at bank level. $G R^{2}$ is the generalized $R^{2}$ criterion of Pesaran and Smith (1994) for 2SLS IV estimation.

* Significance at the $10 \%$ level.

*** Significance at the $5 \%$ level.

*** Significance at the $1 \%$ level. 
Table 6

Determinants of net interest margin (NIM) with crisis interactions

\begin{tabular}{|c|c|c|c|c|c|c|c|c|}
\hline & \multicolumn{2}{|c|}{ Total sample (i) } & \multicolumn{2}{|c|}{ Savings banks (ii) } & \multicolumn{2}{|c|}{ Cooperative banks (iii) } & \multicolumn{2}{|c|}{ Other banks (iv) } \\
\hline & Coeff. & Elast. & Coeff. & Elast. & Coeff. & Elast. & Coeff. & Elast. \\
\hline Lerner index (overall) & $\begin{array}{l}0.073^{* * *} \\
(0.0037)\end{array}$ & 11.496 & $\begin{array}{l}0.073^{* * *} \\
(0.0045)\end{array}$ & 13.688 & $\begin{array}{l}0.077^{* * *} \\
(0.0041)\end{array}$ & 11.405 & $\begin{array}{l}0.059^{* * *} \\
(0.0144)\end{array}$ & 7.957 \\
\hline Operating cost & $\begin{array}{l}1.345^{* * *} \\
(0.0898)\end{array}$ & 12.785 & $\begin{array}{l}1.417^{* * *} \\
(0.1362)\end{array}$ & 12.935 & $\begin{array}{l}1.507^{* * *} \\
(0.0860)\end{array}$ & 14.493 & $\begin{array}{l}0.824^{* * *} \\
(0.2701)\end{array}$ & 8.031 \\
\hline Term spread (asset-liability) & $\begin{array}{l}-0.065^{* * *} \\
(0.0068)\end{array}$ & -0.018 & $\begin{array}{l}-0.070^{* * * *} \\
(0.0110)\end{array}$ & -0.016 & $\begin{array}{l}-0.070^{* * *} \\
(0.0071)\end{array}$ & -0.021 & $\begin{array}{l}-0.055 \\
(0.0479)\end{array}$ & -0.002 \\
\hline Term spread $\times$ crisis & $\begin{array}{l}0.317^{* * *} \\
(0.0315)\end{array}$ & 0.080 & $\begin{array}{l}0.381^{* * *} \\
(0.0491)\end{array}$ & 0.118 & $\begin{array}{l}0.334^{* * *} \\
(0.0315)\end{array}$ & 0.081 & $\begin{array}{l}0.126 \\
(0.1553)\end{array}$ & 0.015 \\
\hline Excess capital & $\begin{array}{l}0.061^{* * *} \\
(0.0048)\end{array}$ & 0.885 & $\begin{array}{l}0.112^{* * *} \\
(0.0112)\end{array}$ & 1.613 & $\begin{array}{l}0.055^{* * *} \\
(0.0048)\end{array}$ & 0.796 & $\begin{array}{l}0.026 \\
(0.0174)\end{array}$ & 0.322 \\
\hline Excess capital $\times$ crisis & $\begin{array}{l}-0.005^{* *} \\
(0.0024)\end{array}$ & -0.019 & $\begin{array}{l}-0.017^{* * *} \\
(0.0065)\end{array}$ & -0.065 & $\begin{array}{l}-0.004^{*} \\
(0.0026)\end{array}$ & -0.015 & $\begin{array}{l}0.047^{*} \\
(0.0254)\end{array}$ & 0.095 \\
\hline Duration gap & $\begin{array}{l}0.248^{* * * *} \\
(0.0229)\end{array}$ & 0.963 & $\begin{array}{l}0.285^{* * *} \\
(0.0444)\end{array}$ & 1.222 & $\begin{array}{l}0.237^{* * *} \\
(0.0304)\end{array}$ & 0.903 & $\begin{array}{l}0.129 \\
(0.1649)\end{array}$ & 0.327 \\
\hline Duration gap $\times$ crisis & $\begin{array}{l}-0.068^{* * * *} \\
(0.0255)\end{array}$ & -0.058 & $\begin{array}{l}-0.090^{* *} \\
(0.0418)\end{array}$ & -0.085 & $\begin{array}{l}-0.055 \\
(0.0350)\end{array}$ & -0.046 & $\begin{array}{l}-0.051 \\
(0.0912)\end{array}$ & -0.026 \\
\hline LIBOR volatility & $\begin{array}{l}1.604^{* * * *} \\
(0.0773)\end{array}$ & 2.405 & $\begin{array}{l}1.616^{* * *} \\
(0.1105)\end{array}$ & 2.824 & $\begin{array}{l}1.676^{* * * *} \\
(0.0896)\end{array}$ & 2.392 & $\begin{array}{l}1.107^{* * * *} \\
(0.2895)\end{array}$ & 1.502 \\
\hline LIBOR volatility $\times$ crisis & $\begin{array}{l}-0.927^{* * *} \\
(0.0613)\end{array}$ & -0.363 & $\begin{array}{l}-0.829^{* * *} \\
(0.1055)\end{array}$ & -0.388 & $\begin{array}{l}-1.041^{* * *} \\
(0.0710)\end{array}$ & -0.387 & $\begin{array}{l}-0.705^{* * *} \\
(0.1659)\end{array}$ & -0.220 \\
\hline Credit risk & $\begin{array}{l}0.000 \\
(0.0007)\end{array}$ & 0.121 & $\begin{array}{l}0.002 \\
(0.0013)\end{array}$ & 0.500 & $\begin{array}{l}0.000 \\
(0.0008)\end{array}$ & 0.046 & $\begin{array}{l}0.001 \\
(0.0046)\end{array}$ & 0.277 \\
\hline Credit-interest covariance & $\begin{array}{l}0.021^{\text {**** }} \\
(0.0016)\end{array}$ & 0.757 & $\begin{array}{l}0.020^{* * *} \\
(0.0019)\end{array}$ & 0.856 & $\begin{array}{l}0.023^{* * * *} \\
(0.0018)\end{array}$ & 0.784 & $\begin{array}{l}0.017^{* * *} \\
(0.0063)\end{array}$ & 0.571 \\
\hline Significance in crisis & & & & & & & & \\
\hline Term spread [ $p$-value] & 80.22 & [0] & 49.38 & {$[0]$} & 87.07 & {$[0]$} & 0.203 & [0.652] \\
\hline Excess capital [ $p$-value] & 155.2 & [0] & 114.2 & {$[0]$} & 125.1 & {$[0]$} & 6.302 & {$[0.012]$} \\
\hline Duration gap [ $p$-value] & 56.71 & [0] & 16.52 & {$[0]$} & 43.61 & {$[0]$} & 0.280 & [0.596] \\
\hline LIBOR volatility [ $p$-value] & 76.19 & [0] & 40.20 & {$[0]$} & 33.45 & [0] & 2.227 & [0.136] \\
\hline Obs. & 16,396 & & 4479 & & 11,524 & & 393 & \\
\hline Number of synthetic banks & 2380 & & 594 & & 1730 & & 56 & \\
\hline$G R^{2}$ & 0.552 & & 0.483 & & 0.607 & & 0.391 & \\
\hline Underid. LM stat. [p-value] & 90.63 & [0] & 59.02 & {$[0]$} & 63.96 & {$[0]$} & 7.709 & [0.006] \\
\hline Kleibergen-Paap F-test & 77.88 & & 47.76 & & 57.08 & & 5.671 & \\
\hline
\end{tabular}

Variables previously denoted Bank-specific variables, Macroeconomic variables, and Revolving portfolios are included in the regressions, but, for the purpose of brevity, are not displayed. Term spread (asset-liability), Excess capital, Duration gap, and LIBOR volatility are additionally interacted with a crisis dummy, indicating the years 2008 and 2009. Significance in crisis reports values and $p$-values of the Wald test of the sum of the parameters of the non-interacted variable and the variable interacted with the crisis dummy (variable $\times$ crisis). All models are estimated using fixed-effects 2 SLS IV regressions, where the specific Lerner index and NII (not displayed) are instrumented with their own first differences. Underid. gives the LM statistic and the p-value for the Kleibergen and Paap (2006) rank test of underidentification. Kleibergen-Paap F-test is the weak instrument statistic for clustered standard errors. Elasticities of variables are displayed on the right next to coefficients and are calculated at sample mean and multiplied by the factor 10 . Elasticities are estimated using chain rules, and are multiplied by -10 if evaluated at a negative sample mean. Standard errors are given in parentheses and are clustered at bank level. $G R^{2}$ is the generalized $R^{2}$ criterion of Pesaran and Smith (1994) for 2SLS IV estimation

* Significance at the $10 \%$ level.

** Significance at the $5 \%$ level.

*** Significance at the $1 \%$ level.

centered banks. During the period from 2005 to 2009, Memmel (2011) estimates the income generated from maturity transformation to be around 30 basis points for savings and cooperative banks, and 7 basis points for other banks. Hence, the risk premia charged in fees are of a similar magnitude and supplement these earnings.

LIBOR volatility, proxying the macroeconomic risk of unexpected changes in the yield curve, is priced significantly in all banking samples and confirms the results of previous studies investigating banks' NIM (e.g. Saunders and Schumacher, 2000; Maudos and Fernández de Guevara, 2004; Maudos and Solís, 2009). Fees charged are about 100 basis points per percentage point of realized volatility, and are the highest for savings banks.

Credit risk is priced with a lower magnitude, but is not significant for other banks, though the inference might suffer from the overly small sample size here. Given positive risk components, as found by the positive coefficients described above, we find positive effects of excess capital for all the samples investigated. The impact of the correlation between interest and credit risk is positive, but only of limited economic magnitude.

Considering the bank-specific variables that are not derived from the model, NII has the expected negative sign indicating that interest income and non-interest income are substitutes. The coefficients for IIP observed for the total sample, savings banks, and cooperative banks are significantly negative, and therefore in variance to the predictions and findings in the literature so far (e.g. Angbazo, 1997; Saunders and Schumacher, 2000; Maudos and Fernández de Guevara, 2004; Maudos and Solís, 2009). The difference to previous findings seems to be due to the NIM of German banks being strongly influenced by operating expenses, which seem to include some effects of implicit interest payments, such as a branch network in close proximity or with access to ATMs.

Inflation has a positive and significant impact. Banks are able to increase the NIM by between 0.46 percentage points and 0.72 percentage points, given a one percentage point increase in inflation. As the NIM includes interest income from assets and expenses from liabilities with maturities of more than one year where contract terms have been negotiated in the past, being able to pass inflation on to the NIM to this extent is economically important. By contrast, GDP growth has a significantly negative impact after controlling for inflation and the yield curve movements captured in the revolving portfolios. A potential explanation is the greater competition on the loan markets during economic upswings driven by lower credit standards. 
Summarizing the results for net intermediation fee income, we find that our model predictions hold. Fees are (somewhat) reduced when positive returns from maturity transformation are expected. Macroeconomic and microeconomic interest rate risk, i.e. LIBOR volatility and the bank-specific duration gap, are priced. Whereas all this holds for the total sample as well as for savings and cooperative banks, we sometimes find a lack of significance for other banks, which may be due to the overly small sample size in some cases. However, whereas LIBOR volatility has a clear impact for other banks, the impact of the duration gap is insignificant and the coefficient is very small. Given that other banks include (large) private commercial banks whose business is less traditional and which have better access to capital markets and are, thus, more likely to manage their smaller duration gap via derivatives rather than on-balance, this result seems plausible.

\subsection{Separation of interest income and interest expenses}

In this section, we run the regressions for the interest income margin (IIM, see Table 4) and the interest expense margin (IEM, see Table 5) separately. Controlling for fair coupon payments from the underlying bonds via revolving portfolios makes it possible, based on Eqs. (10) and (11), to test the model-derived hypotheses for the loan and deposit fee separately. This analysis also reveals which balance sheet side, loans or deposits, drives the results discovered for the NIM in Section 4.2. When we run the separate regressions, the share of the explained variation (the generalized $R^{2}$ ) increases-compared to the regression for the net interest margin-from around 0.54 to 0.87 in both cases.

Lerner indices are significant for both interest income and interest expenses, indicating that banks can exploit their market power by increasing intermediation fees on both the asset and liability side, as predicted by our model. Comparing the magnitude of the coefficients and elasticities, the results imply that market power has a much greater impact on the asset side than on the liability side.

By contrast, operating costs seem to be solely priced on the liability side. Whereas the coefficients are insignificant or, at most, weakly significant on the asset side, we find highly significant coefficients (except for the sub-sample of other banks) on the liability side.

The term spread, being an indicator of how far banks price expected excess holding period returns, reveals the expected negative coefficient on the asset side, and here, the effect is even greater than that observed for the net interest income. Banks are willing to lower loan fees by $9-17$ basis points for a 100 basis point steepness in the yield curve. For liabilities, contrary to the model predictions, we find positive coefficients, though only significant for the sub-sample of cooperative banks and in the total sample. Moreover, the size of the coefficients (0.01-0.02) and elasticities (0.002-0.004) are economically negligible. Given the generally low deposit rates and their stickiness, this suggests that the majority of deposit fees are extracted via market power and the pricing of operating cost rather than charging customers an extra fee for expected valuation losses from an increasing term structure. This does not seem to be implausible, as valuation risk is less relevant for deposits-compared to loans-owing to the shorter maturity.

Similar effects can be observed for the pricing of on-balance interest rate risk measured by the duration gap. For the asset side, we find the expected positive and significant (except for other banks) coefficients ( 0.37 and 0.57 for savings and cooperative banks, respectively). This implies that banks charge extra intermediation fees when a long-term loan exposes them to interest rate risk from maturity transformation. This fee also increases with the risk of unexpected changes in the yield curve, measured by
LIBOR volatility, with coefficients ranging from 0.93 to 1.67 . For the liability side, the duration gap also has positive coefficients (0.005-0.08), but they are only significant for cooperative banks and in the total sample. LIBOR volatility has a positive and significant (except for other banks) impact on deposit fees as well; however, these volatility coefficients and elasticities are much smaller than those for the asset side. This finding contradicts the theoretical model, but confirms previous evidence (Gambacorta, 2008) and suggests that Ho and Saunders-type models neglect a certain relevant relationship between deposit fee and volatility as already discussed in Section 3.2.1.

Concerning a bank's risk aversion, measured by its excess capital, positive and significant (except for other banks) coefficients are found on the asset side. However, results (sign and significance) are mixed for the liability side. ${ }^{22}$

Credit risk has the expected positive sign and is significant. The correlation between interest and credit risk is significantly negative for both the asset and liability side. The positive effect on the NIM is, therefore, explained by the higher magnitude of the elasticities on the liability side. However, the negative coefficients contradict the model's predictions for the IEM. A potential explanation is that a higher correlation between interest and credit risk increases the overall risk in credit-risky fixed-income exposures which could encourage customers to place funds in guaranteed deposits. This extra deposit supply would allow banks to increase fees, i.e. to pay lower rates.

Non-interest income increases both the IIM and the IEM. The effect is most pronounced for savings banks, while in the other bank sample it is only significant for the IIM at the $10 \%$ level. Given that NII increases interest income and expenses, the negative effect found for the NIM-an indicator for the substitute relationship between NII and overall interest income-is driven by interest expenses rising more strongly than interest income. ${ }^{23}$

One effect that seems to be astonishing is that, in general, banks decrease interest expenses with rising inflation, while the opposite holds true for savings banks. This might be caused by the latter's public ownership mandate, which could make them more willing to raise deposit rates with increasing inflation.

To summarize, we find that loan fees depend negatively on expected holding period returns and positively on macroeconomic interest rate risk (LIBOR volatility) and microeconomic duration gaps. This means that banks pass part of the positive expected holding period returns to customers but price higher risk charges when loans compound a large duration gap and when interest rate uncertainty is high. On the liability side, we do not find an economically relevant impact of expected excess holding period returns. This suggests that banks do not charge higher fees in deposits as a means of compensating for higher valuation risk compared to

\footnotetext{
${ }^{22}$ Focusing on short-term bank rates rather than intermediation fees in Italy, Gambacorta (2008) finds that high endowments of excess capital lead to significantly different adjustments of loan rates but not of deposit rates, which is consistent with our results.

${ }^{23}$ For robustness we re-run regressions for the NIM, the IIM, and the IEM using the share of non-interest income to total income following Stiroh (2004), and the diversification measure proposed by Stiroh and Rumble (2006). Diversification is defined as one minus a Herfindahl Hirshman Index of squared interest income and non-interest income shares. Results for both alternative NII proxies are robust to the ones reported. Fee share is negatively related to the NIM for savings and cooperative banks. This result is driven by fee share having a stronger positive impact on the IEM compared to the IIM. Higher degrees of diversification are negatively related to fee shares, and therefore significantly positively related to the NIM for savings and cooperative banks. Effects are driven by a significantly negative impact on the IEM, but no significant impact is observed for the IIM. Additionally, including the share of trading income as an explanatory variable or in the calculation of the diversification measure does not change our results significantly, but diminishes statistical significance. The share of trading income itself is always insignificant, even for other banks. Hence, our results are driven by fee income, which serves as a substitute income source for interest income.
} 
Table 7

Determinants of interest margin (IIM \& IEM) with crisis interactions.

\begin{tabular}{|c|c|c|c|c|c|c|c|c|}
\hline & \multicolumn{2}{|c|}{ Total sample (i) } & \multicolumn{2}{|c|}{ Savings banks (ii) } & \multicolumn{2}{|c|}{ Cooperative banks (iii) } & \multicolumn{2}{|c|}{ Other banks (iv) } \\
\hline & Coeff. & Elast. & Coeff. & Elast. & Coeff. & Elast. & Coeff. & Elast. \\
\hline \multicolumn{9}{|c|}{ Panel A: Interest income margin (IIM) } \\
\hline Lerner index (assets) & $\begin{array}{l}0.060^{* * *} \\
(0.0041)\end{array}$ & 5.455 & $\begin{array}{l}0.049^{* * *} \\
(0.0060)\end{array}$ & 4.695 & $\begin{array}{l}0.066^{* * *} \\
(0.0066)\end{array}$ & 5.954 & $\begin{array}{l}0.067^{* * *} \\
(0.0120)\end{array}$ & 5.565 \\
\hline Operating cost & $\begin{array}{l}-0.395^{* * *} \\
(0.0624)\end{array}$ & -1.817 & $\begin{array}{l}-0.370^{* * *} \\
(0.1284)\end{array}$ & -1.452 & $\begin{array}{l}-0.530^{* * *} \\
(0.0599)\end{array}$ & -2.563 & $\begin{array}{l}-0.159 \\
(0.2509)\end{array}$ & -0.778 \\
\hline Term spread (assets) & $\begin{array}{l}-0.199^{* * *} \\
(0.0237)\end{array}$ & -0.198 & $\begin{array}{l}-0.139^{* * *} \\
(0.0271)\end{array}$ & -0.143 & $\begin{array}{l}-0.161^{* * *} \\
(0.0288)\end{array}$ & -0.158 & $\begin{array}{c}-0.171^{*} \\
(0.0930)\end{array}$ & -0.166 \\
\hline Term spread $\times$ crisis & $\begin{array}{l}0.386^{* * * *} \\
(0.0714)\end{array}$ & 0.108 & $\begin{array}{l}0.300^{* * *} \\
(0.0795)\end{array}$ & 0.089 & $\begin{array}{l}0.618^{* * * *} \\
(0.0771)\end{array}$ & 0.171 & $\begin{array}{l}-0.615^{*} \\
(0.3487)\end{array}$ & -0.114 \\
\hline Excess capital & $\begin{array}{l}0.041^{* * *} \\
(0.0070)\end{array}$ & 0.254 & $\begin{array}{l}0.040^{* * * *} \\
(0.0089)\end{array}$ & 0.212 & $\begin{array}{l}0.056^{* * *} \\
(0.0075)\end{array}$ & 0.366 & $\begin{array}{l}-0.014 \\
(0.0199)\end{array}$ & -0.079 \\
\hline Excess capital $\times$ crisis & $\begin{array}{l}-0.006 \\
(0.0040)\end{array}$ & -0.009 & $\begin{array}{l}0.003 \\
(0.0069)\end{array}$ & 0.004 & $\begin{array}{l}-0.016 \\
(0.0040)\end{array}$ & -0.024 & $\begin{array}{l}0.028 \\
(0.0401)\end{array}$ & 0.026 \\
\hline Duration gap & $\begin{array}{l}0.375^{* * *} \\
(0.0464)\end{array}$ & 0.627 & $\begin{array}{l}0.449^{* * *} \\
(0.0884)\end{array}$ & 0.714 & $\begin{array}{l}0.520^{* * *} \\
(0.0742)\end{array}$ & 0.895 & $\begin{array}{l}0.083 \\
(0.1051)\end{array}$ & 0.097 \\
\hline Duration gap $\times$ crisis & $\begin{array}{l}-0.047 \\
(0.0323)\end{array}$ & -0.017 & $\begin{array}{l}-0.110^{* *} \\
(0.0499)\end{array}$ & -0.039 & $\begin{array}{l}-0.041 \\
(0.0310)\end{array}$ & -0.015 & $\begin{array}{l}0.153 \\
(0.1318)\end{array}$ & 0.036 \\
\hline LIBOR volatility & $\begin{array}{l}3.389^{* * * *} \\
(0.2598)\end{array}$ & 2.185 & $\begin{array}{l}2.355^{* * *} \\
(0.2704)\end{array}$ & 1.527 & $\begin{array}{l}3.641^{* * *} \\
(0.3861)\end{array}$ & 2.345 & $\begin{array}{l}3.154^{* * *} \\
(0.6412)\end{array}$ & 1.973 \\
\hline LIBOR volatility $\times$ crisis & $\begin{array}{l}-3.261^{* * *} \\
(0.2968)\end{array}$ & -0.550 & $\begin{array}{l}-2.530^{* * * *} \\
(0.3122)\end{array}$ & -0.439 & $\begin{array}{l}-3.852^{* * * *} \\
(0.4097)\end{array}$ & -0.646 & $\begin{array}{l}-1.687^{* * *} \\
(0.7597)\end{array}$ & -0.243 \\
\hline Credit risk & $\begin{array}{l}0.008^{* * *} \\
(0.0017)\end{array}$ & 0.850 & $\begin{array}{l}0.010^{* * * *} \\
(0.0018)\end{array}$ & 1.069 & $\begin{array}{l}0.005^{* * * *} \\
(0.0010)\end{array}$ & 0.508 & $\begin{array}{l}0.015^{*} \\
(0.0084)\end{array}$ & 1.666 \\
\hline Credit-interest covariance & $\begin{array}{l}-0.036^{* * * *} \\
(0.0024)\end{array}$ & -0.574 & $\begin{array}{l}-0.030^{* * * *} \\
(0.0024)\end{array}$ & -0.476 & $\begin{array}{l}-0.043^{* * * *} \\
(0.0037) \\
\end{array}$ & -0.677 & $\begin{array}{l}-0.027^{* * * *} \\
(0.0063)\end{array}$ & -0.407 \\
\hline \multicolumn{9}{|l|}{ Significance in crisis } \\
\hline Term spread [ $p$-value] & 6.532 & [0.011] & 5.583 & {$[0.018]$} & 60.32 & [0] & 4.594 & [0.032] \\
\hline Excess capital [p-value] & 22.80 & [0] & 19.35 & [0] & 35.82 & {$[0]$} & 0.0883 & {$[0.766]$} \\
\hline Duration gap [ $p$-value] & 37.93 & {$[0]$} & 18.09 & [0] & 50.95 & {$[0]$} & 2.737 & {$[0.098]$} \\
\hline LIBOR volatility [ $p$-value] & 0.567 & {$[0.451]$} & 1.650 & [0.199] & 6.255 & {$[0.012]$} & 14.97 & [0] \\
\hline$G R^{2}$ & 0.868 & & 0.896 & & 0.891 & & 0.661 & \\
\hline Underid. LM stat. [p-value] & 72.75 & {$[0]$} & 36.73 & {$[0]$} & 37.00 & {$[0]$} & 7.797 & {$[0.005]$} \\
\hline Kleibergen-Paap F-test & 97.96 & & 62.26 & & 37.08 & & 5.171 & \\
\hline \multicolumn{9}{|c|}{ Panel B: Interest expense margin (IEM) } \\
\hline Lerner index (deposits) & $\begin{array}{l}-0.010^{* * *} \\
(0.0005)\end{array}$ & -0.894 & $\begin{array}{l}-0.017^{* * *} \\
(0.0011)\end{array}$ & -1.381 & $\begin{array}{l}-0.009^{* * *} \\
(0.0005)\end{array}$ & -0.775 & $\begin{array}{l}-0.021^{* * * *} \\
(0.0039)\end{array}$ & -1.957 \\
\hline Operating cost & $\begin{array}{l}-0.235^{* * *} \\
(0.0459)\end{array}$ & -2.080 & $\begin{array}{l}-0.582^{* * *} \\
(0.0686)\end{array}$ & -3.971 & $\begin{array}{l}-0.264^{* * *} \\
(0.0211)\end{array}$ & -2.546 & $\begin{array}{l}-0.055 \\
(0.2125)\end{array}$ & -0.543 \\
\hline Term spread (liabilities) & $\begin{array}{l}0.009^{*} \\
(0.0048)\end{array}$ & 0.015 & $\begin{array}{l}-0.010 \\
(0.0093)\end{array}$ & -0.017 & $\begin{array}{l}0.027^{* * * *} \\
(0.0049)\end{array}$ & 0.045 & $\begin{array}{l}0.010 \\
(0.0528)\end{array}$ & 0.018 \\
\hline Term spread $\times$ crisis & $\begin{array}{l}-0.034 \\
(0.0211)\end{array}$ & -0.011 & $\begin{array}{l}-0.043 \\
(0.0390)\end{array}$ & -0.014 & $\begin{array}{l}-0.048^{* *} \\
(0.0231)\end{array}$ & -0.016 & $\begin{array}{l}0.008 \\
(0.2283)\end{array}$ & 0.002 \\
\hline Excess capital & $\begin{array}{l}0.004 \\
(0.0032)\end{array}$ & 0.051 & $\begin{array}{l}0.034^{* * *} \\
(0.0060)\end{array}$ & 0.326 & $\begin{array}{l}0.002 \\
(0.0028)\end{array}$ & 0.020 & $\begin{array}{l}-0.028^{* *} \\
(0.0131)\end{array}$ & -0.291 \\
\hline Excess capital $\times$ crisis & $\begin{array}{l}-0.008^{* * *} \\
(0.0028)\end{array}$ & -0.023 & $\begin{array}{l}-0.022^{* * *} \\
(0.0051)\end{array}$ & -0.055 & $\begin{array}{l}-0.002 \\
(0.0029)\end{array}$ & -0.005 & $\begin{array}{l}-0.038 \\
(0.0272)\end{array}$ & -0.067 \\
\hline Duration gap & $\begin{array}{l}0.018 \\
(0.0189)\end{array}$ & 0.059 & $\begin{array}{l}-0.024 \\
(0.0335)\end{array}$ & -0.069 & $\begin{array}{l}0.036^{*} \\
(0.0192)\end{array}$ & 0.125 & $\begin{array}{l}-0.055 \\
(0.1103)\end{array}$ & -0.121 \\
\hline Duration gap $\times$ crisis & $\begin{array}{l}0.050^{* *} \\
(0.0214)\end{array}$ & 0.036 & $\begin{array}{l}-0.007 \\
(0.0313)\end{array}$ & -0.005 & $\begin{array}{l}0.125^{\text {**** }} \\
(0.0235)\end{array}$ & 0.093 & $\begin{array}{l}0.205^{* *} \\
(0.0849)\end{array}$ & 0.090 \\
\hline LIBOR volatility & $\begin{array}{l}0.321^{* * *} \\
(0.0496)\end{array}$ & 0.401 & $\begin{array}{l}0.674^{* * *} \\
(0.0610)\end{array}$ & 0.791 & $\begin{array}{l}0.317^{* * *} \\
(0.0354)\end{array}$ & 0.407 & $\begin{array}{l}0.319 \\
(0.2413)\end{array}$ & 0.375 \\
\hline LIBOR volatility $\times$ crisis & $\begin{array}{l}-0.275^{* * *} \\
(0.0819)\end{array}$ & -0.090 & $\begin{array}{l}-0.657^{* * * *} \\
(0.1150)\end{array}$ & -0.206 & $\begin{array}{l}-0.486^{* * * *} \\
(0.0784)\end{array}$ & -0.162 & $\begin{array}{l}-0.408 \\
(0.4426)\end{array}$ & -0.110 \\
\hline Credit-interest covariance & $\begin{array}{l}-0.009^{* * *} \\
(0.0009)\end{array}$ & -0.268 & $\begin{array}{l}-0.014^{* * *} \\
(0.0010)\end{array}$ & -0.399 & $\begin{array}{l}-0.009^{* * *} \\
(0.0006)\end{array}$ & -0.293 & $\begin{array}{l}-0.015^{* * *} \\
(0.0051) \\
\end{array}$ & -0.440 \\
\hline \multicolumn{9}{|l|}{ Significance in crisis } \\
\hline Term spread [ $p$-value] & 1.430 & {$[0.232]$} & 1.868 & {$[0.172]$} & 0.878 & {$[0.349]$} & 0.006 & [0.939] \\
\hline Excess capital [ $p$-value] & 1.203 & {$[0.273]$} & 3.732 & {$[0.053]$} & 0.004 & {$[0.952]$} & 5.379 & {$[0.020]$} \\
\hline Duration gap [ $p$-value] & 8.350 & {$[0.004]$} & 0.612 & {$[0.434]$} & 34.61 & {$[0]$} & 0.938 & {$[0.333]$} \\
\hline LIBOR volatility [ $p$-value] & 0.723 & [0.395] & 0.0421 & {$[0.837]$} & 6.887 & [0.009] & 0.071 & {$[0.790]$} \\
\hline$G R^{2}$ & 0.869 & & 0.883 & & 0.884 & & 0.792 & \\
\hline Underid. LM stat. [p-value] & 91.07 & {$[0]$} & 173.6 & {$[0]$} & 561.3 & {$[0]$} & 8.188 & {$[0.004]$} \\
\hline Kleibergen-Paap F-test & 72.30 & & 195.4 & & 1314 & & 6.048 & \\
\hline Obs. & 16,396 & & 4479 & & 11,524 & & 393 & \\
\hline Number of synthetic banks & 2380 & & 594 & & 1730 & & 56 & \\
\hline
\end{tabular}

Variables previously denoted Bank-specific variables, Macroeconomic variables, and Revolving portfolios are included in the regressions, but, for the purpose of brevity, are not displayed. Term spread, Excess capital, Duration gap, and LIBOR volatility are additionally interacted with a crisis dummy, indicating the years 2008 and 2009 . Significance in crisis reports values and $p$-values of the Wald test of the sum of the parameters of the non-interacted variable and the variable interacted with the crisis dummy (variable $\times$ crisis). All models are estimated using fixed-effects 2SLS IV regressions, where Lerner index and NII (not displayed) are instrumented with their own first differences. Underid. gives the LM statistic and the $p$-value for the Kleibergen and Paap (2006) rank test of underidentification. Kleibergen-Paap $F$-test is the weak instrument statistic for clustered standard errors. Elasticities of variables are displayed on the right next to coefficients and are calculated at sample mean and multiplied by the factor 10 . Elasticities are estimated using chain rules, and are multiplied by -10 if evaluated at a negative sample mean. Standard errors are given in parentheses and are clustered at bank level. $G R^{2}$ is the generalized $R^{2}$ criterion of Pesaran and Smith (1994) for 2SLS IV estimation.

* Significance at the $10 \%$ level.

** Significance at the $5 \%$ level.

*** Significance at the $1 \%$ level. 
funding in the money market. We find evidence that macroeconomic interest rate risk is priced. However, the coefficient does not have the model-derived sign. Our results on the impact of the duration gap are mixed, suggesting that the effect, if it exists, is not strong and only valid for the smallest of the banks in our sample, i.e. cooperative banks. All in all, the different pictures for assets and liabilities imply that the results for the NIM are mainly driven by the asset side.

\subsection{Impact of financial crisis}

The last two years of our sample period from 2000 to 2009 are years of financial turmoil. Although the German banking system was on the whole less affected than other systems, some of our results might be influenced by this time of high uncertainty. To analyze possible effects, we repeat the regressions from Tables $3-5$, but additionally interact the variables we are most interested in, i.e. term spread, duration gap, and LIBOR volatility, with a dummy for the crisis years 2008 and 2009. We also interact excess capital as a proxy for risk aversion that may play an important role in times of crisis. It should be noted that, since LIBOR volatility is not bank-specific, any estimation of the impact of the interacted LIBOR volatility may suffer from the absence of cross-sectional variation as it covers only two years in the time series dimension.

Tables 6 and 7 report the results for the NIM, and for the IIM and IEM, respectively. For the sake of brevity, they do so only for the model-derived variables. ${ }^{24}$ In the following, we concentrate our analysis on the four variables which we interacted.

First, examining results for the NIM in Table 6, we find that the non-interacted coefficients of the term spread are again negative, and in general slightly more pronounced and of the same significance compared to the whole sample period reported in Table 3. They range from -0.07 for savings and cooperative banks to -0.055 for other banks. The interacted coefficients capturing the diverging impact during the financial crisis are positive and exceed those previously presented in terms of their magnitude (from 0.381 to 0.126 ). The respective sums of both coefficients (e.g. $-0.07+0.381=0.311$ for savings banks) represent the pricing impact during the financial crisis. They are positive, and tests are highly significant for all but the other bank sample. ${ }^{25}$ This suggests that the negative impact of the term spread on net intermediation fees-as predicted by our model-holds but is distorted during the financial crisis.

Analogous analyses for the remaining variables show that the microeconomic duration gap and the macroeconomic LIBOR volatility keep their sign and significance in the crisis years, except for other banks where LIBOR volatility becomes insignificant. Likewise for savings and cooperative banks, the initial coefficient of LIBOR volatility is reduced by more than $50 \%$ during the financial crisis.

Regarding excess capital, we find that the financial crisis had no economically relevant impact in the case of savings and cooperative banks. For the sample of other banks, non-interacted coefficients are insignificant (0.026), but adding the interacted coefficient $(0.026+0.047=0.073)$ turns the overall effect significantly positive with a $p$-value of $1.2 \%$, as can be seen in the second line, fourth column in "significance in crisis" at the bottom of the table. This implies that the overall effect for other banks found in Table 3 is mainly driven by the financial crisis, a time in which equity was of the greatest value to them.

\footnotetext{
24 The results for the unreported variables are qualitatively very similar to the results presented in Tables 3-5. Minor differences appear for the significance levels of the net revolving portfolios compared to Table 3 for the NIM and the macroeconomic variables, i.e. GDP growth and inflation rate, compared to Table 5 for the IEM.

${ }^{25}$ Values and $p$-values of the Wald test of the sum of the parameters of the noninteracted variable and the variable interacted with the crisis dummy (variable $x$ crisis) are provided under "significance in crisis" at the bottom of the table.
}

Turning to the disentangled results for interest income and expenses in Table 7, we see that the positive effect, reported above, of the term spread on the NIM during the crisis years is driven by the asset side, i.e. the IIM. Non-interacted coefficients are significantly negative for the IIM in all samples, in line with expectations. However, high positive interacted coefficients (except for other banks) overcompensate for these effects during the financial crisis. Only in the case of other banks are the interacted coefficients highly negative, with the result that they strengthen the negative impact observed for the non-interacted coefficients. By contrast, for liabilities, the sum of coefficients capturing the effect of the term spread during the financial crisis is not significant in any regression. During normal times, again, we observe slightly positive significant coefficients solely for cooperative banks, as already shown in Table 5.

For the duration gap, in qualitative terms, we find the same results for the asset side as in our previous analyses. It is positively priced in both normal times and the crisis years, except for other banks owing to insignificant effects. On the liability side, we find the expected positive coefficients during normal times solely for the cooperative banks sample. However, interacted coefficients are significantly positive for cooperative and other banks and almost four times higher than in the non-interacted case. The overall effect during the financial crisis, i.e. the sum of coefficients, is positive and significant for the cooperative banks. The significance in the other bank sample might again suffer from the small sample size. This suggests that many banks with a higher duration gap reduced deposit fees in the crisis years in order to stabilize their funding at a time when external funding, in general, was more expensive.

A surprising effect can be found for LIBOR volatility; however, as mentioned above, this has to be interpreted with caution. Whereas the non-interacted coefficients for both the asset and liability side are positive and significant as in the previous analyses of Tables 4 and 5, the interacted coefficients are negative and highly significant, leading to an insignificant combined effect in most cases. On the asset side, the effect only remains significant for other banks, however, turning significantly negative for cooperatives. Remembering the reduced coefficients found for the NIM, the analysis suggests that banks were unable to price the record-high volatility in interbank market rates during the financial crisis to the same degree as LIBOR volatility during normal times.

With regard to excess capital endowments, against the predictions of the theoretical model, we still find a significantly positive impact for cooperative banks on the liability side. However, the crisis led to a significant reduction in the previously observed effect. For other banks, the crisis enforced the pricing of equity in line with the model, i.e. excess capital leads to reductions in interest expenses. On the asset side, no significantly different pricing pattern can be observed.

\section{Concluding remarks}

In this paper we analyze how interest risk exposure from maturity transformation is priced into banks' intermediation fees. We extend the theoretical dealership model of Ho and Saunders (1981) to incorporate loans and deposits with differing maturities, making the bank sensitive to valuation risk when positive shifts in the yield curve diminish the market value of equity. In so doing, we explicitly integrate one of the central functions of financial intermediation, that of maturity transformation, into the model. The model implies that the fees banks charge on loans and deposits depend on both the macroeconomic risk of unexpected changes in interest rates and the bank-specific microeconomic exposure to this risk, i.e. the maturity gap, as well as expected holding period returns from maturity transformation. 
We test the model-implied hypotheses for the German commercial banking sector, a bank-based financial system in which maturity transformation evolves as a consequence of liquidity creation by financial intermediaries. Many of these chiefly small and medium-sized banks manage interest risk on-balance, which makes the dataset suitable for our analysis.

In contrast to earlier studies, we investigate not only net interest income but also the interest income and expense margin separately. Our results show that all banks price the macroeconomic risk of interest rate volatility by charging higher loan fees and paying higher deposit rates, where our model-in line with other Ho and Saunders-type models-would predict lower deposit rates. The microeconomic risk of the specific on-balance duration gap is priced by the savings and cooperative banks in the net interest income margin, and these results are driven via loan pricing on the asset side. On the liability side, we find that interest rate risk exposure is priced only by cooperative banks. The fees of larger private commercial banks with access to capital markets, on the other hand, are not sensitive to on-balance interest rate risk.

A limitation of our model is that it addresses maturity transformation in a single-period context. In a multi-period model, an inversion of the term structure, where the risk of losses due to increased funding costs can materialize, could be allowed for. Asset-liability rebalancing with respect to the shape of the yield curve could be imbedded as well. Moreover, a multi-period model might allow the bank's and customers' expectations about the future shape of the yield curve to be included. Based on their expectations the bank and its customers might develop preferences for multi-period contracts (loans or deposits) or decide to roll over single-period contracts.

\section{Acknowledgments}

This paper represents the authors' personal opinions and does not necessarily reflect the views of the Deutsche Bundesbank. The research for this paper was partly conducted while Benedikt Ruprecht was a visiting researcher at the Deutsche Bundesbank. He would like to thank the Deutsche Bundesbank for its hospitality and Cusanuswerk for its financial support. We are grateful to the participants of seminars at Barcelona GSE, the Deutsche Bundesbank, University of Liechtenstein, the 3rd Conference on "Global Financial Markets", Jena, the 1st Workshop on "Banks and Financial Markets", Augsburg, the 12th Symposium on Finance, Banking, and Insurance, Karlsruhe, the 4th IFABS Conference, Valencia, the 21st EFMA Conference, Barcelona, the 27th EEA, Málaga, and the 19th German Finance Association (DGF) Meeting, Hanover. We would especially like to thank an anonymous referee, Benjamin Böninghausen, Ulrich Hege, Frank Heid, Thomas Katzschner, Moshe Kim, Lars Norden and Sofia Ramos for their helpful comments on an earlier draft of this paper, and Thomas Kick for providing data. Financial support from the competence center for Global Business Management at the University of Augsburg is gratefully acknowledged. All remaining errors are our own.

\section{Appendix A. Supplementary data}

Supplementary data associated with this article can be found, in the online version, at http://dx.doi.org/10.1016/j.jbankfin.2014.12. 001 .

\section{References}

Albertazzi, U., Gambacorta, L., 2009. Bank profitability and the business cycle Journal of Financial Stability 5 (4), 393-409.

Allen, L., 1988. The determinants of bank interest margins: a note. Journal of Financial and Quantitative Analysis 23 (2), 231-235.
Allen, F., Gale, D., 1997. Financial markets, intermediaries, and intertemporal smoothing. Journal of Political Economy 105 (3), 523-546.

Allen, F., Santomero, A.M., 2001. What do financial intermediaries do? Journal of Banking and Finance 25 (2), 271-294.

Angbazo, L., 1997. Commercial bank net interest margins, default risk, interest-rate risk, and off-balance sheet banking. Journal of Banking and Finance 21 (1), 55-

Bhattacharya, S., Thakor, A.V., 1993. Contemporary banking theory. Journal of Financial Intermediation 3 (1), 2-50.

Blanchard, O., Dell'Ariccia, G., Mauro, P., 2010. Rethinking macroeconomic policy. Journal of Money, Credit and Banking 42, 199-215.

Borio, C., Zhu, H., 2012. Capital regulation, risk-taking and monetary policy: missing link in the transmission mechanism? Journal of Financial Stability 8 (4) 236-251.

Brock, P.L., Suarez, L.R., 2000. Understanding the behavior of bank spreads in Latin America. Journal of Development Economics 63 (1), 113-134.

Brunner, A., Decressin, J., Hardy, D., Kudela, B., 2004. Germany's three-pillar banking system: cross-country perspectives in Europe. International Monetary Fund, Washington, DC, Occasional Paper No. 233.

Brunnermeier, M.K., Oehmke, M., 2013. The maturity rat race. Journal of Finance 68 (2), 483-521.

Brunnermeier, M.K., Yogo, M., 2009. A note on liquidity risk management. American Economic Review Papers and Proceeding 99 (2), 578-583.

Busch, R., Kick, T., 2009. Income diversification in the German banking industry. Working Paper. Deutsche Bundesbank Discussion Paper Series 2: Banking and Financial Studies No. 9/2009.

Campbell, J.Y., Ammer, J., 1993. What moves the stock and bond markets? A variance decomposition for long-term asset returns. Journal of Finance 48 (1), 3-37.

Carbó, S.V., Rodríguez, F.F., 2007. The determinants of bank margins in European banking. Journal of Banking and Finance 31 (7), 2043-2063.

Claeys, S., Vander Vennet, R., 2008. Determinants of bank interest margins in Central and Eastern Europe: a comparison with the West. Economic Systems 32 (2), 197-216.

Cochrane, J.H., Piazzesi, M., 2005. Bond risk premia. American Economic Review 95 (1), 138-160.

Demirgüc-Kunt, A., Huizinga, H., 1999. Determinants of commercial bank interest margins and profitability: some international evidence. The World Bank Economic Review 13 (2), 379-408.

Ehrmann, M., Worms, A., 2004. Bank networks and monetary policy transmission. Journal of the European Economic Association 2 (6), 1148-1171.

Fama, E.F., Bliss, R.R., 1987. The information in long-maturity forward rates. American Economic Review 77 (4), 680-692.

Fama, E.F., French, K.R., 1989. Business conditions and expected returns on stocks and bonds. Journal of Financial Economics 25 (1), 23-49.

Flannery, M.J. James, C.M., 1984. The effect of interest rate changes on the common stock returns of financial institutions. Journal of Finance 39 (4), 1141-1153.

Freixas, X., Rochet, J.-C., 2008. Microeconomics of Banking, second ed. MIT Press.

Froot, K.A., Stein, J.C., 1998. Risk management, capital budgeting, and capital structure policy for financial institutions: an integrated approach. Journal of Financial Economics 47 (1), 55-82.

Gambacorta, L., 2008. How do banks set interest rates? European Economic Review $52(5), 792-819$

Gambacorta, L., Mistrulli, P.E., 2004. Does bank capital affect lending behavior? Journal of Financial Intermediation 13 (4), 436-457.

Greenbaum, S.I., Thakor, A.V., 2004. Contemporary Financial Intermediation, second ed. Butterworth Heinemann.

Hellwig, M., 1994. Liquidity provision, banking, and the allocation of interest rate risk. European Economic Review 38 (7), 1363-1389.

Ho, T.S., Saunders, A., 1981. The determinants of bank interest margins: theory and empirical evidence. Journal of Financial and Quantitative Analysis 16 (4), 581 600.

Ilmanen, A., 1995. Time-varying expected returns in international bond markets. Journal of Finance 50 (2), 481-506.

Kleibergen, F. Paap, R., 2006. Generalized reduced rank tests using the singular value decomposition. Journal of Econometrics 133 (1), 97-126.

Lepetit, L., Nys, E., Rous, P., Tarazi, A., 2008. The expansion of services in European banking: Implications for loan pricing and interest margins. Journal of Banking and Finance 32 (11), 2325-2335.

Maudos, J., Fernández de Guevara, J., 2004. Factors explaining the interest margin in the banking sectors of the European Union. Journal of Banking and Finance 28 (9), 2259-2281.

Maudos, J., Fernández de Guevara, J., 2007. The cost of market power in banking: social welfare loss vs cost inefficiency. Journal of Banking and Finance 31 (7), 2103-2125.

Maudos, J., Solís, L., 2009. The determinants of net interest income in the Mexican banking system: an integrated model. Journal of Banking and Finance 33 (10) $1920-1931$.

McShane, R. Sharpe, I., 1985. A time series/cross section analysis of the determinants of Australian trading bank loan/deposit interest margins: 1962 1981. Journal of Banking and Finance 9 (1), 115-136.

Memmel, C., 2008. Which interest rate scenario is the worst one for a bank? evidence from a tracking bank approach for German savings and cooperative banks. International Journal of Banking Accounting and Finance 1 (1) 85-104.

Memmel, C., 2011. Banks' exposure to interest rate risk, their earnings from term transformation, and the dynamics of the term structure. Journal of Banking and Finance 35 (2), 282-289. 
Nguyen, J., 2012. The relationship between net interest margin and noninterest income using a system estimation approach. Journal of Banking and Finance 36 (9), 2429-2437.

Pesaran, M.H., Smith, R.J., 1994. A generalized $R^{2}$ criterion for regression models estimated by the instrumental variables method. Econometrica 62 (3), 705710.

Purnanandam, A., 2007. Interest rate derivatives at commercial banks: an empirical investigation. Journal of Monetary Economics 54 (6), 1769-1808.

Saunders, A., Schumacher, L., 2000. The determinants of bank interest rate margins: an international study. Journal of International Money and Finance 19 (6), 813 832.

Schmidt, R.H., Hackethal, A., Tyrell, M., 1999. Disintermediation and the role of banks in Europe: an international comparison. Journal of Financial Intermediation $8(1-2), 36-67$.
Sealey Jr., C.W., Lindley, J.T., 1977. Inputs, outputs, and a theory of production and cost at depository financial institutions. Journal of Finance 32 (4), 1251-1266. Segura, A., Suarez, J., 2012. Dynamic, maturity transformation. Working Paper CEMFI

Stiroh, K., 2004. Do community banks benefit from diversification. Journal of Financial Services Research 25, 135-160.

Stiroh, K. Rumble, A., 2006. The dark side of diversification: the case of US financial holding companies. Journal of Banking and Finance 30 (8), 2131-2161.

Stock, J.H., Yogo, M., 2005. Testing for weak instruments in linear IV regressions. In: Andrews, D.W.K., Stock, J.H. (Eds.), Identification and Inference for Econometric Models: Essays in Honor of Thomas J. Rothenberg. Cambridge University Press, pp. 80-108 (Ch. 5).

Wooldridge, J.M., 2001. Applications of generalized methods of moments estimation. Journal of Economic Perspectives 15 (4), 87-100. 


\section{Determinants of Bank Interest Margins: Impact of Maturity Transformation

\author{
Internet Appendix
}

November 2014

Note: References in the form of Section number, (number), and Table number refer to the respective sections, equations, and tables in the paper. 


\section{Contents}

A Generalized model: multi-output framework 2

$\begin{array}{lr}\text { B Lerner indices } & 8\end{array}$

$\begin{array}{ll}\text { C Modified duration gaps } & 11\end{array}$

D Revolving portfolios $\quad 13$

$\begin{array}{ll}\text { E Robustness } & 14\end{array}$

E.1 GMM . . . . . . . . . . . . . . . . . . . . 15

E.2 Alternative margins . . . . . . . . . . . . . . 16

$\begin{array}{lr}\text { References } & 17\end{array}$ 


\section{Appendix A Generalized model: multi-output frame-}

\section{work}

To generalize our model from Section 2 to a multi-output model, we allow the bank to additionally sell a second asset class $N$ that we interpret similarly to Carbó and Rodríguez (2007) and Maudos and Solís (2009) as non-traditional banking (NTB) activities. For example, we could think of loan commitments representing typical off-balance sheet business. The present value of the NTB position held by the bank is denoted $N_{0}$ and the value in $T$ is given by $\left(1+r_{N}+\tilde{Z}_{N}\right) N_{0}$, where $r_{N}$ is the expected return and $\tilde{Z}_{N}$ is a normal random variable with expectation zero and variance $\sigma_{N}^{2}$ capturing the valuation risk per $T$. The covariance between $\tilde{Z}_{N}$ and the loan risk $\tilde{Z}_{L}=\tilde{Z}_{I}+\tilde{Z}_{C}\left(\right.$ deposit risk $\left.\tilde{Z}_{D}\right)$ is denoted $\sigma_{L N}\left(\sigma_{N D}\right) .{ }^{1}$ Managing the NTB portfolio generates cost $C\left(N_{0}\right)$.

As in the case of loans, the bank earns an up-front fee $b_{N}$ when selling a new NTB with exogenous transaction size $Q_{N}$ that arrives with intensity $\lambda_{N}$, assuming $Q_{N}=Q_{L}$ for ease of computation in the following. ${ }^{2}$ Analogously to our original model, the intensity for a new NTB (loan) arrival decreases with the NTB (loan) fee $b_{N}\left(b_{L}\right)$, but it increases with the loan (NTB) fee $b_{L}\left(b_{N}\right)$. This allows us — as in Allen (1988), Carbó and Rodríguez (2007) and Maudos and Solís (2009) - to capture price-driven substitution effects in customers' demand between traditional and non-traditional banking business.

\footnotetext{
${ }^{1}$ To keep formulae simple in the following, we do not decompose the loan risk into interest rate risk and credit risk as it is done in Section 2. Note that the following relations hold by definition: $\sigma_{L}^{2}=\sigma_{I}^{2}+2 \sigma_{I C}+\sigma_{C}^{2}, \sigma_{L D}=\sigma_{I D}+\sigma_{C D}$ and $\sigma_{L N}=\sigma_{I N}+\sigma_{C N}$.

${ }^{2}$ The assumption $Q_{N}=Q_{L}$ can easily be relaxed, but we find it also realistic in the case of loan commitments that can be seen as substitute products for loans.
} 
The intensity for deposits remains unchanged compared to Section 2, i.e. we set:

$$
\begin{aligned}
& \lambda_{D}=\alpha_{D}-\beta_{D} \times a, \\
& \lambda_{L}=\alpha_{L}-\beta_{L} \times b_{L}+\delta_{N} \times b_{N}, \\
& \lambda_{N}=\alpha_{N}-\beta_{N} \times b_{N}+\delta_{L} \times b_{L},
\end{aligned}
$$

where $\delta_{N}$ and $\delta_{L}>0$ denote the cross-elasticities of demand. Note that the derivation and the model results from Section 2 can be achieved as a special case by setting $N_{0}=$ $Q_{N}=\delta_{N}=\delta_{L}=0$.

Given this setup, the bank's present wealth is $W_{0}=L_{0}+N_{0}-D_{0}+M_{0}$, and the value in $T$ equals:

$$
W_{T}=\left(1+r_{L}+\tilde{Z}_{L}\right) L_{0}+\left(1+r_{N}+\tilde{Z}_{N}\right) N_{0}-\left(1+r_{D}+\tilde{Z}_{D}\right) D_{0}+(1+r) M_{0}-C,
$$

where $C=C\left(L_{0}\right)+C\left(N_{0}\right)+C\left(D_{0}\right)$ denotes total cost. Expected wealth per $T$ equals $\bar{W}=E\left(W_{T}\right)=\left(1+r_{L}\right) L_{0}+\left(1+r_{N}\right) N_{0}-\left(1+r_{D}\right) D_{0}+(1+r) M_{0}-C$. Based on $W-\bar{W}=\tilde{Z}_{L} L_{0}+\tilde{Z}_{N} N_{0}-\tilde{Z}_{0} D_{0}$ and using second-order Taylor series expansion of $U$ around $\bar{W}$ as in, e.g. Angbazo (1997) and Maudos and Fernández de Guevara (2004), we obtain the expected end-of-period utility:

$$
\begin{aligned}
E U(W) & =U(\bar{W})+U^{\prime}(\bar{W}) E(W-\bar{W})+\frac{1}{2} U^{\prime \prime}(\bar{W}) E\left((W-\bar{W})^{2}\right) \\
& =U(\bar{W})+\frac{1}{2} U^{\prime \prime}(\bar{W})\left[\sigma_{L}^{2} L_{0}^{2}+\sigma_{N}^{2} N_{0}^{2}+2 \sigma_{L N} L_{0} N_{0}-2 \sigma_{L D} L_{0} D_{0}-2 \sigma_{N D} N_{0} D_{0}+\sigma_{D}^{2} D_{0}^{2}\right] .
\end{aligned}
$$


If a new loan (deposit) arrives, the loan (deposit) position increases by $Q_{L}\left(Q_{D}\right)$ and the money market account changes by $-\left(1-b_{L}\right) Q_{L}\left(+\left(1+b_{D}\right) Q_{D}\right)$ because the loan (deposit) is financed via (put into) the money market account and the fee is invested in it. In the case of NTB, we assume that the fee is also invested in the money market account, but the NTB need not get be financed when conducted, which we find realistic, for example, in the case of loan commitments. ${ }^{3}$ Consequently, the money market account increases by $b_{N} Q_{N}$. Thus, the bank's wealth $W \mid Q_{x}$ in $T$, given that a single transaction $x=L, N, D$ occurs, is:

$$
\begin{aligned}
& W \mid Q_{L}=W_{T}+\left(1+r_{L}+\tilde{Z}_{L}\right) Q_{L}-(1+r)\left(1-b_{L}\right) Q_{L}-C\left(Q_{L}\right), \\
& W \mid Q_{N}=W_{T}+\left(1+r_{N}+\tilde{Z}_{N}\right) Q_{N}+(1+r) b_{N} Q_{N}-C\left(Q_{N}\right), \\
& W \mid Q_{D}=W_{T}-\left(1+r_{D}+\tilde{Z}_{D}\right) Q_{D}+(1+r)(1+a) Q_{D}-C\left(Q_{D}\right) .
\end{aligned}
$$

This implies:

$$
W \mid Q_{L}-\bar{W}=\tilde{Z}_{L}\left(L_{0}+Q_{L}\right)+\tilde{Z}_{N} N_{0}-\tilde{Z}_{D} D_{0}+\left[\left(1+r_{L}\right)-(1+r)\left(1-b_{L}\right)\right] Q_{L}-C\left(Q_{L}\right)
$$

$$
W \mid Q_{N}-\bar{W}=\tilde{Z}_{L} L_{0}+\tilde{Z}_{N}\left(N_{0}+Q_{N}\right)-\tilde{Z}_{D} D_{0}+\left[\left(1+r_{N}\right)+(1+r) b_{N}\right] Q_{N}-C\left(Q_{N}\right)
$$

$$
W \mid Q_{D}-\bar{W}=\tilde{Z}_{L} L_{0}+\tilde{Z}_{N} N_{0}-\tilde{Z}_{D}\left(D_{0}+Q_{D}\right)+\left[(1+r)(1+a)-\left(1+r_{D}\right)\right] Q_{D}-C\left(Q_{D}\right)
$$

\footnotetext{
${ }^{3}$ This assumption can easily be changed. In cases where NTB is fully financed via the money market account, the term $1+r_{N}$ is replaced by $r_{N}-r$ in the final equations (A.20) and (A.21).
} 
Based on (A.6) to (A.11), we calculate analogously to (A.5) the expected end-of-period utility $E U\left(W \mid Q_{x}\right)=U(\bar{W})+U^{\prime}(\bar{W}) E\left(W \mid Q_{x}-\bar{W}\right)+\frac{1}{2} U^{\prime \prime}(\bar{W}) E\left(\left(W \mid Q_{x}-\bar{W}\right)^{2}\right), x=$ $L, N, D$ via second-order Taylor series approximation around $\bar{W}$ and afterwards the changes in expected utility, given that the respective transaction occurs, $\Delta E U\left(W \mid Q_{x}\right)=E U\left(W \mid Q_{x}\right)-$ $E U(W)$, which yields:

$$
\begin{aligned}
& \Delta E U\left(W \mid Q_{L}\right)=U^{\prime}(\bar{W})\left[\left[\left(1+r_{L}\right)-(1+r)\left(1-b_{L}\right)\right] Q_{L}-C\left(Q_{L}\right)\right] \\
& +\frac{1}{2} U^{\prime \prime}(\bar{W})\left[\sigma_{L}^{2}\left(2 L_{0} Q_{L}+Q_{L}^{2}\right)+2 \sigma_{L N} Q_{L} N_{0}-2 \sigma_{L D} Q_{L} D_{0}\right. \\
& \left.+\left[\left[\left(1+r_{L}\right)-(1+r)\left(1-b_{L}\right)\right] Q_{L}-C\left(Q_{L}\right)\right]^{2}\right], \\
& \left.\Delta E U\left(W \mid Q_{N}\right)=U^{\prime}(\bar{W})\left[\left[\left(1+r_{N}\right)+(1+r) b_{N}\right)\right] Q_{N}-C\left(Q_{N}\right)\right] \\
& +\frac{1}{2} U^{\prime \prime}(\bar{W})\left[\sigma_{N}^{2}\left(2 N_{0} Q_{N}+Q_{N}^{2}\right)+2 \sigma_{L N} Q_{N} L_{0}-2 \sigma_{N D} Q_{N} D_{0}\right. \\
& \left.+\left[\left[\left(1+r_{N}\right)+(1+r) b_{N}\right] Q_{N}-C\left(Q_{N}\right)\right]^{2}\right], \\
& \Delta E U\left(W \mid Q_{D}\right)=U^{\prime}(\bar{W})\left[\left[(1+r)(1+a)-\left(1+r_{D}\right)\right] Q_{D}-C\left(Q_{D}\right)\right] \\
& +\frac{1}{2} U^{\prime \prime}(\bar{W})\left[\sigma_{D}^{2}\left(2 D_{0} Q_{D}+Q_{D}^{2}\right)-2 \sigma_{L D} Q_{D} L_{0}-2 \sigma_{N D} Q_{D} N_{0}\right. \\
& \left.+\left[\left[(1+r)(1+a)-\left(1+r_{D}\right)\right] Q_{D}-C\left(Q_{D}\right)\right]^{2}\right] .
\end{aligned}
$$

The bank sets fees to maximize its expected end-of-period utility, i.e. the problem of maximization is as follows:

$$
\max _{a, b_{L}, b_{N}} E U(\Delta W)=\lambda_{D} \Delta E U\left(W \mid Q_{D}\right)+\lambda_{L} \Delta E U\left(W \mid Q_{L}\right)+\lambda_{N} \Delta E U\left(W \mid Q_{N}\right),
$$


given that at most a single transaction occurs. First-order conditions imply:

$$
\begin{aligned}
& \frac{\partial E U(\Delta W)}{\partial b_{L}}=-\beta_{L} \Delta E U\left(W \mid Q_{L}\right)+\lambda_{L} \frac{\partial \Delta E U\left(W \mid Q_{L}\right)}{\partial b_{L}}+\delta_{L} \Delta E U\left(W \mid Q_{N}\right)=0, \\
& \frac{\partial E U(\Delta W)}{\partial b_{N}}=+\delta_{N} \Delta E U\left(W \mid Q_{L}\right)+\lambda_{N} \frac{\partial \Delta E U\left(W \mid Q_{N}\right)}{\partial b_{N}}-\beta_{N} \Delta E U\left(W \mid Q_{N}\right)=0, \\
& \frac{\partial E U(\Delta W)}{\partial a}=-\beta_{D} \Delta E U\left(W \mid Q_{D}\right)+\lambda_{D} \frac{\partial \Delta E U\left(W \mid Q_{D}\right)}{\partial a}=0 .
\end{aligned}
$$

Solving equations (A.16) to (A.18) is straightforward. For example, (A.16) means:

$$
\begin{aligned}
& 0= \frac{\partial \Delta E U(W)}{\partial b_{L}} \\
&=-\beta_{L}\left[U^{\prime}(\bar{W})\left[\left[\left(1+r_{L}\right)-(1+r)\left(1-b_{L}\right)\right] Q_{L}-C\left(Q_{L}\right)\right]\right. \\
& \quad\left.\quad+\frac{1}{2} U^{\prime \prime}(\bar{W})\left[\sigma_{L}^{2}\left(2 L_{0} Q_{L}+Q_{L}^{2}\right)+2 \sigma_{L N} N_{0} Q_{L}-2 \sigma_{L D} Q_{L} D_{0}\right]\right] \\
&+\left(\alpha_{L}-\beta_{L} b_{L}+\delta_{N} b_{N}\right) U^{\prime}(\bar{W})(1+r) Q_{L} \\
&\left.+\delta_{L}\left[U^{\prime}(\bar{W})\left[\left(1+r_{N}\right)+(1+r) b_{N}\right)\right] Q_{N}-C\left(Q_{N}\right)\right] \\
&\left.\quad+\frac{1}{2} U^{\prime \prime}(\bar{W})\left[\sigma_{N}^{2}\left(2 N_{0} Q_{N}+Q_{N}^{2}\right)+2 \sigma_{L N} L_{0} Q_{N}-2 \sigma_{N D} Q_{N} D_{0}\right]\right]
\end{aligned}
$$

where we make - analogously to Ho and Saunders (1981) and subsequent model extensions such as Angbazo (1997) and Maudos and Fernández de Guevara (2004) — the assumption that second-order terms of fees, expected returns and operating cost, e.g. $\left[\left[\left(1+r_{L}\right)-(1+r)\left(1-b_{L}\right)\right] Q_{L}-C\left(Q_{L}\right)\right]^{2}$ in (A.12), are negligible. Multiplying (A.19) by $\frac{-1}{U^{\prime}(\bar{W})} \frac{1}{Q_{L}} \frac{1}{\beta_{L}} \frac{1}{(1+r)}$, using $Q_{L}=Q_{N}$, and collecting and rearranging terms yields the optimal 
loan fee:

$$
\begin{aligned}
b_{L}^{*}= & \frac{1}{2} \frac{\alpha_{L}}{\beta_{L}}+\frac{1}{2} \frac{C\left(Q_{L}\right)}{Q_{L}(1+r)}-\frac{1}{2} \frac{r_{L}-r}{(1+r)} \\
& -\frac{1}{4} \frac{U^{\prime \prime}(\bar{W})}{U^{\prime}(\bar{W})} \frac{\left[\sigma_{L}^{2}\left(2 L_{0}+Q_{L}\right)+2 \sigma_{L N} N_{0}-2 \sigma_{L D} D_{0}\right]}{(1+r)} \\
& +\frac{\delta_{L}}{\beta_{L}}\left[\frac{1}{2}\left(\frac{\delta_{N}}{\delta_{L}}+1\right) b_{N}-\frac{1}{2} \frac{C\left(Q_{N}\right)}{Q_{N}(1+r)}+\frac{1}{2} \frac{1+r_{N}}{(1+r)}\right. \\
& \left.+\frac{1}{4} \frac{U^{\prime \prime}(\bar{W})}{U^{\prime}(\bar{W})} \frac{\left[\sigma_{N}^{2}\left(2 N_{0}+Q_{N}\right)+2 \sigma_{L N} L_{0}-2 \sigma_{N D} D_{0}\right]}{(1+r)}\right] .
\end{aligned}
$$

Analogously, we obtain representations for the optimal NTB and deposit fee:

$$
\begin{aligned}
b_{N}^{*}=\frac{1}{2} \frac{\alpha_{N}}{\beta_{N}}+\frac{1}{2} \frac{C\left(Q_{N}\right)}{Q_{N}(1+r)}-\frac{1}{2} \frac{1+r_{N}}{(1+r)} & \\
- & \frac{1}{4} \frac{U^{\prime \prime}(\bar{W})}{U^{\prime}(\bar{W})} \frac{\left[\sigma_{N}^{2}\left(2 N_{0}+Q_{N}\right)+2 \sigma_{L N} L_{0}-2 \sigma_{N D} D_{0}\right]}{(1+r)} \\
+ & \frac{\delta_{N}}{\beta_{N}}\left[\frac{1}{2}\left(\frac{\delta_{L}}{\delta_{N}}+1\right) b_{L}-\frac{1}{2} \frac{C\left(Q_{L}\right)}{Q_{L}(1+r)}+\frac{1}{2} \frac{r_{L}-r}{(1+r)}\right. \\
& \left.+\frac{1}{4} \frac{U^{\prime \prime}(\bar{W})}{U^{\prime}(\bar{W})} \frac{\left[\sigma_{L}^{2}\left(2 L_{0}+Q_{L}\right)+2 \sigma_{L N} N_{0}-2 \sigma_{L D} D_{0}\right]}{(1+r)}\right], \\
a^{*}= & \frac{1}{2} \frac{\alpha_{D}}{\beta_{D}}+\frac{1}{2} \frac{C\left(Q_{D}\right)}{Q_{D}(1+r)}+\frac{1}{2} \frac{r_{D}-r}{(1+r)} \\
& -\frac{1}{4} \frac{U^{\prime \prime}(\bar{W})}{U^{\prime}(\bar{W})} \frac{\left[\sigma_{D}^{2}\left(2 D_{0}+Q_{D}\right)-2 \sigma_{L D} L_{0}-2 \sigma_{N D} N_{0}\right]}{(1+r)} .
\end{aligned}
$$

The first two lines of the optimal loan fee $b_{L}^{*}(\mathrm{~A} .20)$ in this generalized model basically coincide with the loan fee $b^{*}(10)$ derived from our model in Section 2. The only exception is the term $2 \sigma_{L N} N_{0}$ measuring the degree of diversification between loans and NTB. By contrast, the last two lines of (A.20) make the key difference between the loan fee in our 
original and the generalized multi-output model. Depending on the sign of $\frac{1}{2}\left(\frac{\delta_{N}}{\delta_{L}}+1\right) b_{N}-$ $\frac{1}{2} \frac{C\left(Q_{N}\right)}{Q_{N}(1+r)}+\frac{1}{2} \frac{1+r_{N}}{(1+r)}+\frac{1}{4} \frac{U^{\prime \prime}(\bar{W})}{U^{\prime}(\bar{W})} \frac{\left[\sigma_{N}^{2}\left(2 N_{0}+Q_{N}\right)+2 \sigma_{L N} L_{0}-2 \sigma_{N D} D_{0}\right]}{(1+r)}-$ remember $\frac{U^{\prime \prime}(\bar{W})}{U^{\prime}(\bar{W})}<0$ - the introduction of a second output can lead to higher or lower optimal loan fees compared to the single-output case, but the sign cannot be specified ex ante, which essentially matches the result obtained by Allen (1988) and Carbó and Rodríguez (2007). The overall effect depends on the cross-elasticities of demand, risk aversion, cost and expected return of NTB as well as its risk characteristics.

Comparing the optimal deposit fee $a^{*}$ of our original model (11) and the generalized model (A.22) produces minor differences. The last summand of (A.22) additionally includes the term $-2 \sigma_{N D} N_{0}$ measuring the hedging relationship between deposits and NTB.

\section{Appendix B Lerner indices}

A single-product Lerner index is defined as the output price minus marginal cost divided by price, and equals the inverse of elasticity of demand for the output:

$$
\frac{i_{T A}^{*}-m c_{T A}}{i_{T A}^{*}}=\frac{1}{N \epsilon_{T A}\left(i_{T A}^{*}\right)}
$$

where $m c_{T A}$ are marginal costs encompassing financial expenses. $\epsilon_{T A}$ represents the elasticity of output demand in a market encompassing $N$ banks. The output price $i$ (the interest rate that the bank charges) is assumed to be exogenous and is proxied by interest income / interest-earning assets. Marginal costs for overall market power are estimated 
from a single-output (total assets, $T A$ ), three-input translog cost function. The input prices comprise: (i) cost of labor $w_{1}$, (ii) cost of physical capital $w_{2}$, and (iii) cost of funding $w_{3}$. The input prices are proxied as: (i) $w_{1}$ personnel cost / number of full-time equivalent employees measured in 1,000; (ii) $w_{2}$ operating cost excluding personnel cost / fixed assets; (iii) $w_{3}$ interest expenses paid / total interest-paying liabilities. Equity $E q$ is included as a net output and a time trend $T r$, specified as time dummies, captures technical change. The translog cost function has the following form and is estimated using fixed bank effects to control for unobserved heterogeneity. The usual symmetry and linear homogeneity in input price restrictions are imposed.

$$
\begin{aligned}
\ln c_{i t}= & \gamma_{i}+\gamma_{A} \ln T A_{i t}+\frac{1}{2} \gamma_{A A}\left(\ln T A_{i t}\right)^{2}+\sum_{h=1}^{3} \gamma_{h} \ln w_{h i t} \\
& +\frac{1}{2} \sum_{h=1}^{3} \sum_{m=1}^{3} \gamma_{h m} \ln w_{h i t} \ln w_{m i t}+\sum_{h=1}^{3} \gamma_{h A} \ln w_{h i t} \ln T A_{i t}+\gamma_{E} \ln E q_{i t} \\
& +\frac{1}{2} \gamma_{E E}\left(\ln E q_{i t}\right)^{2}+\gamma_{E A} \ln E q_{i t} \ln T A_{i t}+\sum_{h=1}^{3} \gamma_{h E} \ln w_{h i t} \ln E q_{i t} \\
& +\gamma_{T} T r+\frac{1}{2} \gamma_{T T}(T r)^{2}+\gamma_{T A} \operatorname{Tr} \ln T A_{i t} \\
& +\sum_{h=1}^{3} \gamma_{T h} \operatorname{Tr} \ln w_{h i t}+\gamma_{T E} \operatorname{Tr} \ln E q_{i t}+\ln u_{i t} .
\end{aligned}
$$

Marginal costs $m c_{T A_{i t}}$ are derived from

$$
m c_{T A_{i t}}=\left[\gamma_{A}+\gamma_{A A} \ln T A_{i t}+\sum_{h=1}^{3} \gamma_{h A} \ln w_{h i t}+\gamma_{E A} \ln E q_{i t}+\gamma_{T A} \operatorname{Tr}\right] \frac{c_{i t}}{T A_{i t}}
$$

Separate Lerner indices for interest-bearing assets and liabilities are derived from firstorder conditions of profit maximization in the Monti-Klein model and expressed as (see 
Freixas and Rochet, 2008, p. 58):

$$
\frac{i^{*}{ }_{L}-i-m c_{L}}{i^{*}{ }_{L}}=\frac{1}{N \epsilon_{L}\left(i^{*}{ }_{L}\right)} ; \quad \frac{i-i^{*}{ }_{D}-m c_{D}}{i^{*}{ }_{D}}=\frac{1}{N \epsilon_{D}\left(i^{*}{ }_{D}\right)}
$$

where $i_{L}, i_{D}$ and $i$ are the interest rates set on loans, deposits and the interbank market, respectively. To estimate the marginal cost, we follow the two-product output approach of Maudos and Fernández de Guevara (2007). $i_{L}$ is proxied to equal interest income / interest-earning assets, and $i_{D}$ equals interest expenses / interest-paying liabilities. The yearly average of the six-month LIBOR rate presents the interbank funding rate. Marginal costs are estimated using a two-product output translog cost function, including loans $L$ and deposits $D$. Loans are proxied by interest-earning assets less bonds held and deposits as total interest-paying liabilities less bonds issued. ${ }^{4}$ The interbank rate is clearly exogenous, and interest expenses on liabilities are now considered to be the output price of deposits, with the result that we only include the two price input factors of labor $\left(w_{1}\right)$ and physical capital $\left(w_{2}\right)$, which are defined in the same way as in the three-input cost function. Again, time dummies control for technical change, while fixed bank effects

\footnotetext{
${ }^{4}$ It is assumed that bond supply and demand are perfectly elastic, that the bank cannot exercise market power in trading bonds, and that bond portfolios are not associated with operating cost. Statistically, bond portfolios are excluded to make the loan and the deposit proxies less correlated to each other. For the same reason, the impact of equity is not controlled for, as equity and interest-paying liabilities would otherwise almost total interest-earning assets.
} 
control for unobserved heterogeneity. The translog cost function takes the following form:

$$
\begin{aligned}
\ln c_{i t}= & \gamma_{i}+\gamma_{L} \ln L_{i t}+\frac{1}{2} \gamma_{L L}\left(\ln L_{i t}\right)^{2}+\gamma_{D} \ln D_{i t}+\frac{1}{2} \gamma_{D D}\left(\ln D_{i t}\right)^{2} \\
& +\gamma_{L D} \ln L_{i t} \ln D_{i t}+\sum_{h=1}^{2} \gamma_{h} \ln w_{h i t}+\frac{1}{2} \sum_{h=1}^{2} \sum_{m=1}^{2} \gamma_{h m} \ln w_{h i t} \ln w_{m i t} \\
& +\sum_{h=1}^{2} \gamma_{h L} \ln w_{h i t} \ln L_{i t}+\sum_{h=1}^{2} \gamma_{h D} \ln w_{h i t} \ln D_{i t}+\gamma_{T} \operatorname{Tr}+\frac{1}{2} \gamma_{T T}(T r)^{2} \\
& +\gamma_{T L} \operatorname{Tr} \ln L_{i t}+\gamma_{T D} \operatorname{Tr} \ln D_{i t}+\sum_{h=1}^{2} \gamma_{T h} \operatorname{Tr} \ln w_{h i t}+\ln u_{i t} .
\end{aligned}
$$

The cost function has been estimated using fixed bank effects. Marginal costs are derived from:

$$
\begin{aligned}
& m c_{L_{i t}}=\left[\gamma_{L}+\gamma_{L L} \ln L_{i t}+\gamma_{L D} \ln D_{i t}+\sum_{h=1}^{2} \gamma_{h L} \ln w_{h i t}+\gamma_{T L} \operatorname{Tr}\right] \frac{c_{i t}}{L_{i t}} \\
& m c_{D_{i t}}=\left[\gamma_{D}+\gamma_{D D} \ln D_{i t}+\gamma_{L D} \ln L_{i t}+\sum_{h=1}^{2} \gamma_{h D} \ln w_{h i t}+\gamma_{T D} \operatorname{Tr}\right] \frac{c_{i t}}{D_{i t}}
\end{aligned}
$$

\section{Appendix C Modified duration gaps}

Table App.1 provides an overview of the different lender and borrower client groups and the time brackets reported in the Deutsche Bundesbank's monthly balance sheet statistics. Note that the brackets are filled according to the initial time to maturity.

For simplicity, we make the following assumptions when calculating the modified duration $\overline{D_{\text {mod }}\left(M_{1}, M_{2}\right)}$ for a specific position and maturity bracket with the boundaries $M_{1}$ and $M_{2}$ : (i) the initial time to maturity is equally distributed between the boundaries;

(ii) the bank has revolvingly invested the same amount in bonds with maturity $M$ where $M_{1}<M<M_{2}$; (iii) all bonds are default-free and continuously pay par yield $r_{f}$.

The modified duration of a continuously par-yield-paying, default-free bond of matu- 
rity $M$ is:

$$
D_{m o d}(M)=\frac{1}{r_{f}}\left(1-\exp \left(-r_{f} M\right)\right)
$$

The modified duration of a portfolio revolvingly investing in such bonds of maturity $M$, i.e. where the residual maturity is equally distributed within the interval $[0, M]$, can be expressed as (see also the Appendix of Memmel, 2011):

$$
\begin{aligned}
\overline{D_{\text {mod }}(M)} & =\int_{t=0}^{M} \frac{1}{M} D_{\text {mod }}(N) d N \\
& =\frac{M-1 / r_{f}\left(1-\exp \left(-r_{f} M\right)\right)}{M r_{f}} .
\end{aligned}
$$

Finally, the modified duration of revolvingly investing in a portfolio of the aforementioned type of bonds of a given maturity bracket from $M_{1}$ to $M_{2}$, with initial maturity being equally distributed between the boundaries, is:

$$
\overline{D_{\text {mod }}\left(M_{1}, M_{2}\right)}=\frac{1}{M_{2}-M_{1}} \int_{M_{1}}^{M_{2}} \overline{D_{\text {mod }}(M)} d M .
$$

Using first-order Taylor series approximations around $r_{f}=0$, equation (C.2) yields:

$$
\overline{D_{\text {mod }}(M)} \approx \frac{1}{2} M-\frac{1}{6} M^{2} r_{f}
$$

and equation (C.3)

$$
\overline{D_{\text {mod }}\left(M_{1}, M_{2}\right)} \approx \frac{1}{4}\left(M_{2}+M_{1}\right)-\frac{1}{18}\left(M_{2}^{2}+M_{1}^{2}+M_{2} \cdot M_{1}\right) r_{f} .
$$


The asset's (liability's) modified duration $D_{\text {mod }}^{A}\left(D_{\text {mod }}^{L}\right)$ is calculated using equations (C.4) and (C.5) employing weighted sums of all the brackets of assets (liabilities) reported in Table App.1. The weights correspond to the proportion of assets (liabilities) in a given bracket relative to total interest-bearing assets (liabilities). The modified duration gap is derived as

$$
D_{\text {gap }}=D_{m o d}^{A}-D_{m o d}^{L} \frac{\text { total interest-paying liabilities }}{\text { total interest-earning assets }}
$$

When no upper boundary for a maturity bracket is reported, it is assumed to be 8 years. For savings accounts, applying legal maturities of 3 and 6 months would clearly overestimate the duration gap. Therefore, we assume $50 \%$ of the volume to be core deposits with long-term maturities of 9.5 and 10 years (depending on the legal maturity), while the other half is assigned its legal maturity (see also Purnanandam, 2007).

\section{Appendix D Revolving portfolios}

The strategy of revolving portfolios is based on the time brackets reported in the Deutsche Bundesbank's monthly balance sheet statistics (see Table App.1) and is illustrated using an example. Imagine a bank that grants solely risk-free loans with a maturity of five years. Whenever a loan falls due, a new five-year loan is granted. Under the assumption of time-invariant business, the residual maturity of the bonds in the bank's portfolio is equally distributed between zero and five years. Memmel (2008) shows that this bank's interest income margin is equal to the five-year moving average of five-year risk-free par- 
yield bonds. For balance sheet positions with a predetermined repricing period (such as loans), the calculation is relatively straightforward. For other positions, we chose the following assumptions:

- Where no upper boundary for a maturity bracket is reported, it is assumed to be 8 years.

- Daily maturities are modeled using the 3-month government par yields in order to reduce the volatility resulting from estimation errors in fitting the lower end of the Svensson term structure.

- Savings deposits are modelled as 50\% core deposits (see also Purnanandam, 2007). Deposits with up to 3-month maturities are modeled as the equally weighted moving average of the 3-month and 9.5-year par yields, deposits with longer maturities as the 6-month and 10-year par yield. Modeling savings deposits as weighted sums of moving averages of long and short-term interest rates is a methodology consistent with the internal IRR management approaches of smaller German banks (see also Memmel, 2011).

\section{Appendix E Robustness}

This section provides robustness checks on the results presented so far by re-estimating the models using a GMM estimator. Furthermore, we estimate our models for alternative, likewise commonly used accounting margins instead of the NIM. For all these regression models, we focus on the overall sample. 


\section{E.1 GMM}

In this section we re-estimate the models for the NIM, IIM, and IEM using an overidentified GMM model. GMM estimators are more efficient than 2SLS OLS estimators, but are potentially biased (Wooldridge, 2001). Since exactly identified models deliver identical results for GMM and 2SLS, we add the level of extraordinary income to total assets to the two instruments already used for the exactly identified 2SLS models. Extraordinary income is not related to interest income and expenses, but may be used to increase market power and is likely to be correlated with the fee income captured in our NII proxy as both. We test the joint hypothesis of instrument exogeneity and the correct specification of the model using Hansen-J statistics.

GMM results are provided in Table App.2 and are very similar to the results presented earlier. The p-value of the Hansen-J test is always insignificant at a level of at least $10 \%$. Compared to the coefficients, the reduction of standard errors gained is quite low. Therefore, the GMM models do not seem to present much in the way of efficiency gains. However, for the NII, the coefficients change for all three interest margins and are significantly negative in the IIM and IEM models. As the GMM estimator might be biased, we will not place too much emphasis on this finding. For the model-derived variables, the GMM model is robust. Only for operating cost in the case of IIM and IEM do we find larger changes in the coefficients. For the IIM, we previously found negative, slightly significant coefficients. Using a GMM model it turns into a significantly positive coefficient, in line with the expectations of the theoretical model. 


\section{E.2 Alternative margins}

In this section we present robustness using alternative, commonly used margin definitions. The gross margin, defined as gross income to total assets, has been investigated by Carbó and Rodríguez (2007). Furthermore, we investigate the wide margin, that is, net interest income to total interest-earning assets, and the narrow margin, i.e. interest income to total interest-earning assets minus interest expenses to total interest-paying liabilities. Both wide and narrow margins are used by Lepetit et al. (2008) and are also similar to margins examined by Brock and Suarez (2000). By definition, the narrow margin is the difference between the IIM and IEM. We use the same explanatory variables as for the NIM. However, as the gross margin includes non-interest income and expenses, we do not include NII as an explanatory variable in this case. Hence, in setting the gross margin, we only instrument the Lerner index with its first lagged difference.

All coefficients presented in Table App.3 have the identical sign and are very similar in magnitude to the coefficients found for the total sample in Table 3. The only exception is the coefficient found for the duration gap in the narrow margin setting, which is significantly negative. However, this does not necessarily contradict our earlier findings. In fact, the narrow margin separately normalizes interest income and expenses to interest-bearing assets and liabilities, respectively, and thus does not reflect possible volume imbalances between respective assets and liabilities. ${ }^{5}$ By contrast, our duration gap proxy (13) does reflect this imbalance by scaling the modified duration of the liability side. Given this different treatment of volume imbalances, it is hard to pass judgement on the expected

\footnotetext{
${ }^{5}$ It should be noted that our other margin definitions, such as the NIM and the wide margin, reflect this imbalance as it has a direct influence on the net interest income.
} 
sign in this empirical setting.

\section{References}

Allen, L., 1988. The determinants of bank interest margins: A note. Journal of Financial and Quantitative Analysis 23 (2), 231-235.

Angbazo, L., 1997. Commercial bank net interest margins, default risk, interest-rate risk, and off-balance sheet banking. Journal of Banking and Finance 21 (1), 55-87.

Brock, P. L., Suarez, L. R., 2000. Understanding the behavior of bank spreads in Latin America. Journal of Development Economics 63 (1), 113-134.

Carbó, S. V., Rodríguez, F. F., 2007. The determinants of bank margins in European banking. Journal of Banking and Finance 31 (7), 2043-2063.

Freixas, X., Rochet, J.-C., 2008. Microeconomics of banking, 2nd Edition. MIT Press.

Ho, T. S., Saunders, A., 1981. The determinants of bank interest margins: Theory and empirical evidence. Journal of Financial and Quantitative Analysis 16 (4), 581-600.

Kleibergen, F., Paap, R., 2006. Generalized reduced rank tests using the singular value decomposition. Journal of Econometrics 133 (1), 97-126.

Lepetit, L., Nys, E., Rous, P., Tarazi, A., 2008. The expansion of services in European banking: Implications for loan pricing and interest margins. Journal of Banking and Finance 32 (11), 2325-2335.

Maudos, J., Fernández de Guevara, J., 2004. Factors explaining the interest margin in the banking sectors of the European Union. Journal of Banking and Finance 28 (9), 2259-2281.

Maudos, J., Fernández de Guevara, J., 2007. The cost of market power in banking: Social welfare loss vs. cost inefficiency. Journal of Banking and Finance 31 (7), 2103-2125.

Maudos, J., Solís, L., 2009. The determinants of net interest income in the Mexican banking system: An integrated model. Journal of Banking and Finance 33 (10), 19201931.

Memmel, C., 2008. Which interest rate scenario is the worst one for a bank? Evidence from a tracking bank approach for German savings and cooperative banks. International Journal of Banking, Accounting and Finance 1 (1), 85-104.

Memmel, C., 2011. Banks' exposure to interest rate risk, their earnings from term transformation, and the dynamics of the term structure. Journal of Banking and Finance $35(2), 282-289$. 
Purnanandam, A., 2007. Interest rate derivatives at commercial banks: An empirical investigation. Journal of Monetary Economics 54 (6), 1769-1808.

Wooldridge, J. M., 2001. Applications of generalized methods of moments estimation. Journal of Economic Perspectives 15 (4), 87-100. 


\section{Tables}

Table App.1: Initial maturities of lender and borrower client groups

\begin{tabular}{lllll}
\hline Position & 1st bracket & 2nd bracket & 3rd bracket & 4th bracket \\
\hline Assets & daily & $\leq 1 \mathrm{y}$. & $>1 \mathrm{y} . \leq 5 \mathrm{y}$. & $>5 \mathrm{y}$. \\
Loans to banks & $\leq 1 \mathrm{y}$. & $>1 \mathrm{y} . \leq 5 \mathrm{y} . \quad>5 \mathrm{y}$. & \\
Loans to non-banks & $\leq 1 \mathrm{y}$. & $>1 \mathrm{y} .2 \mathrm{y} . \quad>2 \mathrm{y}$. & \\
Bonds held & daily & $\leq 1 \mathrm{y}$. & $>1 \mathrm{y} . \leq 2 \mathrm{y}$. & $>2 \mathrm{y}$. \\
Liabilities & daily & $\leq 1 \mathrm{y}$. & $>1 \mathrm{y} . \leq 2 \mathrm{y}$. & $>2 \mathrm{y}$. \\
Loans from banks & $\leq 3 \mathrm{~m}$. & $>3 \mathrm{~m}$. & \\
Loans from non-banks & $\leq 1 \mathrm{y}$. & $>1 \mathrm{y} . \leq 2 \mathrm{y} . \quad>2 \mathrm{y}$. & \\
$\begin{array}{l}\text { Subordinated debt } \\
\text { Savings accounts }\end{array}$ & Bonds issued & & & \\
\hline \hline
\end{tabular}

Maturity brackets reported in the Deutsche Bundesbank's monthly balance sheet statistics for different asset and liability classes. 
Table App.2: Determinants of interest margins - GMM models

\begin{tabular}{|c|c|c|c|}
\hline \multirow{2}{*}{\multicolumn{4}{|c|}{ Model-determined variables }} \\
\hline & & & \\
\hline Lerner index & $\begin{array}{l}0.048^{* * *} \\
(0.0020)\end{array}$ & $\begin{array}{l}0.052 * * * \\
(0.0031)\end{array}$ & $\begin{array}{l}-0.011 * * * \\
(0.0005)\end{array}$ \\
\hline \multirow[t]{2}{*}{ Operating cost } & $0.674^{* * *}$ & $0.327^{* * *}$ & 0.038 \\
\hline & $(0.0487)$ & $(0.0517)$ & $(0.0416)$ \\
\hline \multirow[t]{2}{*}{ Term spread } & $-0.011^{* *}$ & $-0.215^{* * *}$ & -0.001 \\
\hline & $(0.0043)$ & $(0.0184)$ & $(0.0047)$ \\
\hline \multirow{2}{*}{ Excess capital } & $0.022^{* * *}$ & $0.052^{* * *}$ & $0.008^{* * *}$ \\
\hline & $(0.0027)$ & $(0.0049)$ & $(0.0028)$ \\
\hline \multirow[t]{2}{*}{ Duration gap } & $0.077^{* * *}$ & $0.368^{* * *}$ & $0.072^{* * *}$ \\
\hline & $(0.0159)$ & $(0.0467)$ & $(0.0206)$ \\
\hline \multirow{2}{*}{ LIBOR volatility } & $0.678^{* * *}$ & $1.526^{* * *}$ & $0.124^{* * *}$ \\
\hline & $(0.0350)$ & $(0.0948)$ & $(0.0138)$ \\
\hline \multirow{2}{*}{ Credit risk } & $0.010^{* * *}$ & $0.017^{* * *}$ & \\
\hline & $(0.0005)$ & $(0.0013)$ & \\
\hline \multirow{2}{*}{ Credit-interest covariance } & $0.015^{* * *}$ & $-0.006^{* * *}$ & $-0.005 * * *$ \\
\hline & $(0.0010)$ & $(0.0005)$ & $(0.0003)$ \\
\hline \multicolumn{4}{|l|}{ Bank-specific variables } \\
\hline \multirow[t]{2}{*}{ NII } & 0.153 & $-0.676^{* * *}$ & $-0.409 * *$ \\
\hline & $(0.1173)$ & $(0.1405)$ & $(0.1624)$ \\
\hline \multirow[t]{2}{*}{ IIP } & -0.037 & -0.021 & $-0.111^{* * *}$ \\
\hline & $(0.0270)$ & $(0.0331)$ & $(0.0254)$ \\
\hline \multirow[t]{2}{*}{ OCR } & $-0.035 * * *$ & $0.145^{* * *}$ & -0.007 \\
\hline & $(0.0072)$ & $(0.0131)$ & $(0.0085)$ \\
\hline \multicolumn{4}{|l|}{ Macroeconomic variables } \\
\hline GDP growth & $\begin{array}{l}-0.065^{* * *} \\
(0.0048)\end{array}$ & $\begin{array}{l}0.070^{* * *} \\
(0.0063)\end{array}$ & $0.011^{* * *}$ \\
\hline \multirow{2}{*}{ Inflation rate } & $0.353^{* * *}$ & $0.349 * * *$ & $\begin{array}{l}(0.0030) \\
0.007\end{array}$ \\
\hline & $(0.0228)$ & $(0.0243)$ & $(0.0069)$ \\
\hline Revolving portfolios & YES & YES & YES \\
\hline Obs. & 16,396 & 16,396 & 16,396 \\
\hline Number of synthetic banks & 2,380 & 2,380 & 2,380 \\
\hline$G R^{2}$ & 0.752 & 0.770 & 0.886 \\
\hline Underid. LM stat. & 243.5 & 120.8 & 44.75 \\
\hline Underid. p-value & 0 & 0 & 0 \\
\hline Kleibergen-Paap F-test weak & 128.5 & 81.51 & 27.09 \\
\hline Hansen-J stat. & 0.675 & 0.006 & 1.721 \\
\hline Hansen-J p-value & 0.411 & 0.936 & 0.190 \\
\hline
\end{tabular}

Dependent variables: net interest margin (NIM), interest income margin (IIM), interest expense margin (IEM). The explanatory variables are those used in sections 4.2 and 4.3. All models are estimated using an overidentified GMM model for the total sample, where Lerner index and NII are instrumented with their first difference and first lag respectively as well as extraordinary income to total assets. Underid. gives the LM statistic and the $p$-value for the Kleibergen and Paap (2006) rank test of underidentification. KleibergenPaap F-test is the weak instrument statistic for clustered standard errors. Hansen J-test is the $\chi^{2}$ statistic of overidentification. Robust standard errors are given in parentheses. Significance at the 10\%/5\%/1\% level is inficated by $* / * * / * * *$. 
Table App.3: Determinants of accounting margins

\begin{tabular}{|c|c|c|c|}
\hline & Gross margin & Wide margin & Narrow margin \\
\hline \multicolumn{4}{|l|}{ Model-determined variables } \\
\hline Lerner index (overall) & $\begin{array}{l}0.064^{* * *} \\
(0.0022)\end{array}$ & $\begin{array}{l}0.071 * * * \\
(0.0045)\end{array}$ & $\begin{array}{l}0.054^{* * *} \\
(0.0057)\end{array}$ \\
\hline \multirow[t]{2}{*}{ Operating cost } & $1.222^{* * *}$ & $1.457^{* * *}$ & $1.195^{* * *}$ \\
\hline & $(0.0409)$ & $(0.1119)$ & $(0.1220)$ \\
\hline \multirow[t]{2}{*}{ Term spread (asset-liabilities) } & $-0.034 * * *$ & $-0.044 * * *$ & $-0.032^{* * *}$ \\
\hline & $(0.0047)$ & $(0.0064)$ & $(0.0066)$ \\
\hline \multirow[t]{2}{*}{ Excess capital } & $0.040^{* * *}$ & $0.054^{* * *}$ & $0.034^{* * *}$ \\
\hline & $(0.0033)$ & $(0.0056)$ & $(0.0059)$ \\
\hline \multirow[t]{2}{*}{ Duration gap } & $0.156^{* * *}$ & $0.110^{* * *}$ & $-0.072^{* *}$ \\
\hline & $(0.0166)$ & $(0.0276)$ & $(0.0363)$ \\
\hline \multirow[t]{2}{*}{ LIBOR volatility } & $0.935^{* * *}$ & $1.064^{* * *}$ & $0.851^{* * *}$ \\
\hline & $(0.0404)$ & $(0.0767)$ & $(0.0949)$ \\
\hline \multirow[t]{2}{*}{ Credit risk } & $0.008^{* * *}$ & $0.009 * * *$ & $0.009^{* * *}$ \\
\hline & $(0.0005)$ & $(0.0007)$ & $(0.0008)$ \\
\hline \multirow[t]{2}{*}{ Credit-interest covariance } & $0.025 * * *$ & $0.028 * * *$ & $0.021^{* * *}$ \\
\hline & $(0.0010)$ & $(0.0022)$ & $(0.0029)$ \\
\hline \multicolumn{4}{|l|}{ Bank-specific variables } \\
\hline NII & & $\begin{array}{l}-1.340^{* * *} \\
(0.1661)\end{array}$ & $\begin{array}{l}-1.068^{* * *} \\
(0.1812)\end{array}$ \\
\hline \multirow{2}{*}{ IIP } & $-0.359 * * *$ & $-0.468^{* * *}$ & $-0.337 * * *$ \\
\hline & $(0.0260)$ & $(0.0676)$ & $(0.0696)$ \\
\hline \multirow[t]{2}{*}{ OCR } & -0.006 & $0.031 * * *$ & $0.059^{* * *}$ \\
\hline & $(0.0082)$ & $(0.0114)$ & $(0.0143)$ \\
\hline \multicolumn{4}{|l|}{ Macroeconomic variables } \\
\hline GDP growth & $\begin{array}{l}-0.106^{* * *} \\
(0.0056)\end{array}$ & $\begin{array}{l}-0.119 * * * \\
(0.0114)\end{array}$ & $\begin{array}{l}-0.084^{* * *} \\
(0.0140)\end{array}$ \\
\hline \multirow[t]{2}{*}{ Inflation rate } & $0.557^{* * *}$ & $0.641^{* * *}$ & $0.497^{* * *}$ \\
\hline & $(0.0238)$ & $(0.0513)$ & $(0.0636)$ \\
\hline Revolving portfolios & YES & YES & YES \\
\hline Obs. & 16,396 & 16,396 & 16,396 \\
\hline Number of synthetic banks & 2,380 & 2,380 & 2,380 \\
\hline$G R^{2}$ & 0.674 & 0.557 & 0.576 \\
\hline Underid. LM stat. & 200.6 & 71.18 & 71.18 \\
\hline Underid. p-value & 0 & 0 & 0 \\
\hline Kleibergen-Paap F-test & 481.3 & 58.23 & 58.23 \\
\hline
\end{tabular}

Dependent variables: Gross margin is gross income to total assets; Wide margin is net interest income to total interest-bearing assets; Narrow margin is IIM minus IEM. Operating cost, non-interest income (NII), opportunity cost of reserves (OCR) and implicit interest payments (IIP) are in relation to total assets. All models are estimated for the overall sample using fixed-effects 2SLS IV regressions, where Lerner index (overall) and NII are instrumented with their own first differences. Underid. gives the LM statistic and the $p$-value for the Kleibergen and Paap (2006) rank test of underidentification. Kleibergen-Paap F-test is the weak instrument statistic for clustered standard errors. Standard errors are given in parentheses and are clustered at bank level. Significance at the $10 \% / 5 \% / 1 \%$ level is indicated by $* /^{* *} / * * *$. 